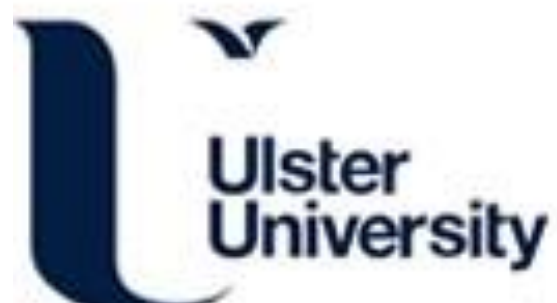

\section{Review and analysis of fire and explosion accidents in maritime transportation}

Baalisampang, T., Abbassi, A., Garaniya, V., Khan, F., \& Dadashzadeh, M. (2018). Review and analysis of fire and explosion accidents in maritime transportation. Ocean Engineering, 158, 350-366.

https://doi.org/10.1016/j.oceaneng.2018.04.022

Link to publication record in Ulster University Research Portal

\section{Published in:}

Ocean Engineering

Publication Status:

Published (in print/issue): 15/06/2018

DOI:

10.1016/j.oceaneng.2018.04.022

\section{Document Version}

Author Accepted version

\section{General rights}

Copyright for the publications made accessible via Ulster University's Research Portal is retained by the author(s) and / or other copyright owners and it is a condition of accessing these publications that users recognise and abide by the legal requirements associated with these rights.

\section{Take down policy}

The Research Portal is Ulster University's institutional repository that provides access to Ulster's research outputs. Every effort has been made to ensure that content in the Research Portal does not infringe any person's rights, or applicable UK laws. If you discover content in the Research Portal that you believe breaches copyright or violates any law, please contact pure-support@ulster.ac.uk. 
Engineering

Elsevier Editorial System(tm) for Ocean

Manuscript Draft

Manuscript Number: OE-D-17-01170R2

Title: Review and analysis of fire and explosion accidents in maritime transportation

Article Type: Review article

Keywords: Shipping accidents; fire and explosion; preventive measures; alternative fuels

Corresponding Author: Professor Faisal Khan, PhD

Corresponding Author's Institution: Memorial University

First Author: Til Baalisampang

Order of Authors: Til Baalisampang ; Rouzbeh Abbassi, PhD; Vikram Garaniya, PhD; Faisal Khan, PhD; Mohammad Dadashzadeh, PhD

Abstract: The globally expanding shipping industry has several hazards such as collision, capsizing, foundering, grounding, stranding, fire, and explosion. Accidents are often caused by more than one contributing factor through complex interaction. It is crucial to identify root causes and their interactions to prevent and understand such accidents. This study presents a detailed review and analysis of fire and/or explosion accidents that occurred in the maritime transportation industry during 1990 to 2015. The underlying causes of fire and/or explosion accidents are identified and analysed. This study also reviewed potential preventative measures to prevent such accidents. Additionally, this study compares properties of alternative fuels and analyses their effectiveness in mitigating fire and explosion hazards. It is observed that Cryogenic Natural Gas (CNG), Liquefied Natural Gas (LNG) and methanol have properties more suitable than traditional fuels in mitigating fire risk and appropriate management of their hazards could make them a safer option to traditional fuels. However, for commercial use at this stage, there exist several uncertainties due to inadequate studies, and technological immaturity. This study provides an insight into fire and/or explosion accident causation and prevention, including the prospect of using alternative fuels for mitigating fire and explosion risks in maritime transportation. 
December 30, 2017

\section{Dear Editor-in-Chief}

I am pleased to resubmit the revised version of the manuscript entitled "Review and analysis of fire and explosion accidents in maritime transportation" for possible publication in Journal of Ocean Engineering. Detailed responses to the reviewer's comments are also included.

This is original work of authors and unpublished. I am corresponding author and all authors are agreed to submit this MS to this journal.

There is no conflict of interest.

Best regards,

Faisal Khan,

Professor and Canada Research Chair (Tier I)

Director, Centre for Risk, Integrity and Safety Engineering (C-RISE)

Process Engineering Department, Memorial University of Newfoundland,

St. John's, NL A1B3X5, Canada

Phone: +1 (709) 864-8939

E-mail: fikhan@mun.ca 


\section{Highlights}

- A detailed review and analysis of fire and explosion accidents in the maritime transportation industry during 1990 to 2015.

- Underlying causes of fire and explosion accidents are identified and analysed.

- Study also reviewed potential preventative measures to prevent such accidents.

- Study provides deep insight into accident causation and prevention, including the prospect of using alternative fuels for maritime transportation. 
Authors sincerely appreciate review of the manuscript and the valuable comments.

Authors have made every attempt to address the reviewer's concern. Authors provide below detailed response to reviewer's comments.

Reviewer \#2:

1. In all sentences and figures, there are mixed expressions such as fire and/or explosion, fire and explosion. Correct expression is needed.

Response: Thank you. Authors agree with the reviewer's concern. 'Fire and/or explosion' is now replaced by 'fire and explosion' in the complete manuscript.

2. In Figure 2 and the description of this figure, there are mixed expressions such as number of fatalities, number of accidents, number of fatal accidents, number of fire and explosion accidents. Which is correct? Correct expression is needed.

Response: Thank you. Reviewer's suggestion is considered. To avoid confusion, 'number of fatalities' and 'number of fire and explosion' are used in the figure legends and index.

3. In "3.1. Prevention and mitigation of human," measures for reducing human error are considered to be very general. It is recommended that you concentrate on reducing human error in fire and/or explosion.

Response: Thank you. Fire and explosion accidents are often caused by generic human error. For example, the major offshore fire and explosion accident (Piper Alpha in 1988) was caused by a generic maintenance-related human error. It is well established that generic human errors in specific circumstances causes major accidents. In present study, safety measures to reduce human error may sound generic, however, they are considered contributing to the causation of fire and explosion accidents.

4. In summary, "It is observed that Cryogenic Natural Gas (CrNG), Liquefied Natural Gas (LNG) and methanol have properties that are more suitable than traditional fuels in mitigating fire risk and appropriate management of their hazards could make them a safer option to traditional fuels". Generally speaking, from the present point of view, gas fuels are more explosive than traditional fuels and are known to be dangerous. 
Your conclusion is that if the conditions of safety management and safety equipment are sufficient, gas-type fuel is considered to be safe. Traditional fuels are also believed to be safer than gas-type fuels if they have adequate safety equipment and control measures. If so, these observations are also expected to be judged in terms of sufficient conditions.

Response: Thank you. This assertion has been made based on comparison of properties of fuels from inherent safety perspective (use of lesser hazardous condition).

Authors agree that gas fuels are prone to severe fire and explosion accidents as compared to liquid fuels. However, when gas fuels are liquefied through refrigeration process, their hazardous properties (such as flammability limits, phase of the fuel, and ignition temperature) are reduced. This makes CrNG, LNG and other similar fuels lesser hazardous.

Authors are not claiming that gas-type fuels are safer than liquid-type fuels, and also it is to mention that methanol in normal operating condition is not a gas. 


\section{Review and analysis of fire and explosion accidents in maritime}

2 transportation

3 Til Baalisampang ${ }^{\mathrm{a}}$, Rouzbeh Abbassi ${ }^{\mathrm{a}, *}$, Vikram Garaniya ${ }^{\mathrm{a}}$, Faisal Khan ${ }^{\mathrm{a}, \mathrm{b}, *}$, Mohammad

4 Dadashzadeh $^{\mathrm{c}}$

5 a National Centre for Maritime Engineering and Hydrodynamics, Australian Maritime

6 College, University of Tasmania, Launceston, Tasmania, Australia

$7 \quad{ }^{\mathrm{b}}$ Centre for Risk, Integrity and Safety Engineering, Faculty of Engineering \& Applied

8 Science, Memorial University of Newfoundland, St. John's, NL, Canada

$9{ }^{\mathrm{c}}$ Hydrogen Safety Engineering and Research Centre (HySAFER), Ulster University,

10 Newtownabbey, Northern Ireland, UK.

*Corresponding Author: Email: fikhan@mun.ca; rouzbeh.abbassi@utas.edu.au

\section{Abstract}

14 The globally expanding shipping industry has several hazards such as collision, capsizing, foundering,

15 grounding, stranding, fire, and explosion. Accidents are often caused by more than one contributing 16 factor through complex interaction. It is crucial to identify root causes and their interactions to prevent

17 and understand such accidents. This study presents a detailed review and analysis of fire and 18 explosion accidents that occurred in the maritime transportation industry during 1990 to 2015 . The

19 underlying causes of fire and explosion accidents are identified and analysed. This study also

20 reviewed potential preventative measures to prevent such accidents. Additionally, this study compares

21 properties of alternative fuels and analyses their effectiveness in mitigating fire and explosion hazards.

It is observed that Cryogenic Natural Gas (CrNG), Liquefied Natural Gas (LNG) and methanol have properties more suitable than traditional fuels in mitigating fire risk and appropriate management of their hazards could make them a safer option to traditional fuels. However, for commercial use at this stage, there exist several uncertainties due to inadequate studies, and technological immaturity. This study provides an insight into fire and explosion accident causation and prevention, including the prospect of using alternative fuels for mitigating fire and explosion risks in maritime transportation.

Keywords: Maritime accidents, fire and explosion, preventive measures, alternative fuels 


\section{Introduction}

The shipping industry is expanding globally, leading to an increase in worldwide shipping traffic (Hetherington et al., 2006; Tournadre, 2014; Yip). The growing number of marine vessels may lead to a rise in maritime hazards and accidents. Akten (2006) stated that shipping is, and always will be, full of risks despite increasing safety standards and improved technology. Celik et al. (2010) stated that the system complexity and automation, human error, human-centred system design, and potential design-based failures are different perspectives for ongoing shipping accidents. Due to this, international maritime authorities have made significant efforts to promote safety in the shipping industry (Hetherington et al., 2006; O’Neil, 2003) but despite this, there are still a high number of shipping accidents reported in recently published statistical reports (Baltic Sea Maritime Incidence Response Group (MIRG), 2017; Darbra and Casal, 2004; Eleftheria et al., 2016; Roberts et al., 2012).

Shipping accidents by type are numerous, but common examples are collision or contact, capsize, foundering, breaking up, grounding, stranding, and fire or explosion (Akten, 2006). Broadly, human error, technical and mechanical failure, and environmental factors are common causes leading to shipping accidents but with different percentages (Karahalios, 2015; Uğurlu et al., 2015). The Major Hazard Incident Data Service (MHIDAS) (2002) database, considered eight types of possible causes of general accident, namely mechanical failure, impact failure, human error, instrumental failure, services failure, violent reaction, external events and upset process conditions. According to Allianz Global Corporate and Specialty (2017) foundering (sunk, submerged) wrecked/stranded (grounded), fire/explosion, collision (involving vessels), machinery damage/failure and hull damage have been the most frequent causes of losses at sea over the past decade (2007-2016).

Accidents are often assigned to a single category such as grounding, fire or explosion, human error, collision and foundering. This type of categorization ignores the fact that often 
accidents are caused by more than one contributing factor or sequence of undesirable events (Papanikolaou et al., 2007; Wagenaar and Groeneweg, 1987). Most literatures relating to shipping accidents (Butt et al., 2013; Bužančić Primorac and Parunov, 2016; Roberts et al., 2013) have highlighted the causal factors for general shipping accidents but root causes of a particular event are often ignored. For instance, human error can lead to collision which in turn may cause fire and explosion. In this case, if there are no causal factors for human error as the root cause, then human error, collision and its subsequent events would not have occurred. In order to prevent the consequences of all these events, causal factors for human error are required to be addressed. This indicates that the determination of root cause and potential safety barriers of any accident type are vital in order to prevent accidents.

In the past, a significant number of shipping accidents involved fire and explosions (Akten, 2004; Roberts and Marlow, 2002; Roberts et al., 2012). For instance, Darbra and Casal (2004) found that $29 \%$ and $17 \%$ of accidents in seaports are caused by fires and explosions respectively. Bulk carrier casualties world-wide, taken from Lloyd's records between 1980 and 2010, confirm that fires and explosions caused 19\% of accidents (Roberts et al., 2013). Weng and Yang (2015) found that the contributing factors in shipping accident mortalities resulting from fire/explosion accidents are, on average, 132\% higher than from accidents where no fire/explosions were involved. According to the report presented by Allianz Global Corporate and Specialty (2016), about 10\% of total losses, between 2006 and 2015, were caused by fire and explosion. From 2007 to 2016, foundering accounts for the highest percentage of losses (50.42\%), followed by wrecked/stranded with $20.57 \%$ with the third highest contributor fire/explosion (9.95\%) (Allianz Global Corporate and Specialty, 2017). The MIRG project (2017) stated that from 2000 to 2015, among different types of marine vessels in European waters, the largest percentage of ship fires and explosions occurred on cargo ships. 
The actual number of fire and explosion accidents could be much higher than the

published statistics because of underreporting issues of maritime accidents (Hassel et al., 2011; Schröder-Hinrichs et al., 2011). It is often found that the number of fatalities from fire and explosion accidents in shipping is comparatively higher than that of other types of accidents. Fire and explosion usually occur unexpectedly which provides little evacuation time for passengers or crew members (National Research Council, 1991).

This shows that the risk of fire and explosion in shipping vessels is high. The consequence of ship fire and explosion depends on the presence and amount of hazardous materials and the employed preventive and control mechanisms. In the absence of appropriate protection and response, even a small error that leads to a fire and explosion event has potential to cause loss of vessels, environmental pollution, injuries, and deaths due to the instantaneous nature of ship fires (Shichuan et al., 2012).

Uğurlu (2016) investigated fire and explosion events that occurred between 1999 and 2013 in tankers transporting hazardous liquid cargoes and identified 13 root causes and five causal factors being violation of entry permit (VEP), violation of work permit (VWP), lack of risk analysis (LRA), deficiency in safety management system (DSMS), and deficiency in planned maintenance system (DPMS). This study was conducted in three stages. In the first stage, significance level of the root causes was determined using Fault Tree Analysis (FTA), in the second stage, the causative factors underlying the root causes were determined and in the final stage, the relationship between the causative factors and root causes was determined. The author argued that hot work, electric arcs, static electricity, and combustible gas accumulation are the most significant root causes of fire and explosion accidents in tankers transporting hazardous liquid cargoes and VWP and LRA are the main causative factors of fire and explosion accidents. 
In this paper, the contributing factors for fire and explosion accidents in maritime

transportation are reviewed based on published full investigation reports and literatures.

Accident investigation reports prepared by different agencies such as National Transport

Safety Board (NTSB), Danish Maritime Accident Investigation Board (DMAIB), Australian

107 Transport Safety Board (ATSB), Federal Bureau of Maritime Casualty Investigation (BSU),

108 Transportation Safety Board of Canada (TSB), European Maritime Safety Agency (EMSA)

109 and Marine Accident Investigation Branch (MAIB) are considered. Publicly available fire

110 and explosion related accidents in maritime transportation between 1990 and 2015 are

111 grouped into five categories according to their main causes, namely human error, mechanical

112 failure, reaction, electrical fault and unknown. The percentage of fire and explosion accidents

113 caused by each causal factor is given in Figure 1.

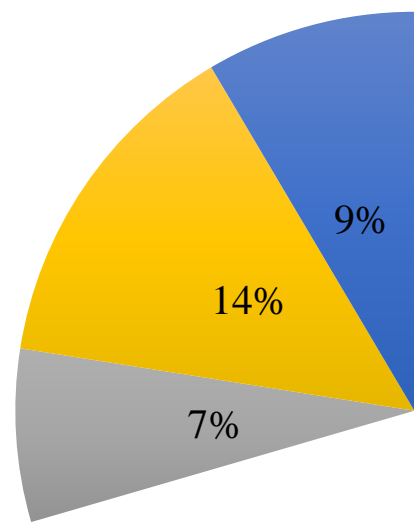

$22 \%$

115 Figure 1. Percentages of fire and explosion accidents

117 number of fatalities and number of accidents in maritime transportation as shown in Figure 2.

118 This indicates that fire and explosion still pose a risk to maritime transportation despite 
119 technological progress. In order to avoid fire and explosion accidents, a comprehensive

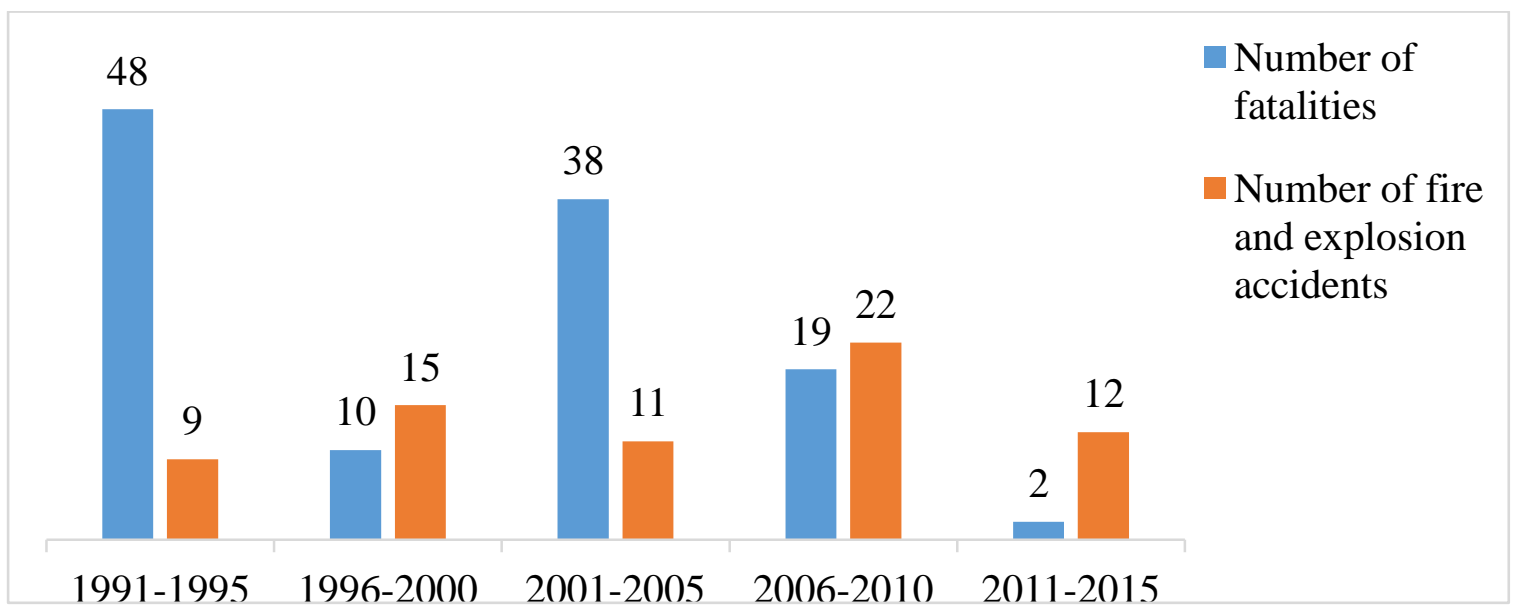

122 Figure 2. Number of fatalities, and number of fire and explosion accidents during 1991-2015

123 Additionally, in this study, potential preventative or mitigation measures are discussed

124 for each type of contributing factor. Identifying sources of flammable materials and replacing

125 them with less hazardous materials may play a positive role in mitigating fire and explosion 126 risks in ship. Marine fuels are highly flammable. In this study, it is found that $31 \%$ fire and 127 explosion events are caused by accidental releases of fuel or lubricating oil in the engine 128 room. Due to this, it is worthwhile to review from a safety perspective flammability 129 properties of alternative fuels. The effectiveness of alternative fuels in mitigating fire and 130 explosion hazards is reviewed based on the comparison of their flammability properties.

131 Therefore, this study would help identify contributing factors for fire and explosion events in 132 maritime transportation and would seek to highlight potential preventive measures.

\section{2. Fire and explosion accidents causations}

134 The causes of fire and explosion in marine operations identified by Kwiecińska

135 (2015), provided characteristics of basic fire causes and the influencing factors in ships.

136 These are namely damage to electrical equipment and cables, damage to mechanical 
137 equipment, damage to ship's hull or its equipment, damage caused by external factors,

1

2

3

4

5

7

8

10

11

12

13

14

15

16

17

18

19

20

21

22

23

24

25

26

27

28

29

30

31

32

33

34

35

36

37

38

39

40

41

42

43

44

45

46

47

48

49

50

51

52

53

54

55

56

57

58

59

60

61

62

63

64

65 
138 damage occurring during maintenance work/repairs, and spontaneous ignition of cargo. The 1 2 
139 author has shown the interrelationship of cause-and-effect links leading to fires on ships and 1 2 3 4 5 7 8 10 
140 argued that spontaneous ignition of cargo is the strongest interaction with other factors. This 1 2 3 4 5 6 7 
141 shows that identifying interrelationships among various causal factors of a broad accident 1 2 3 4 5 6 7 8 9 10 
142 category helps to explore the underlying causes. Thus, in order to identify causal and root 1 2 3 4 5 7 8 10 
Fire and explosion accidents in maritime transportation from 1990 to 2015

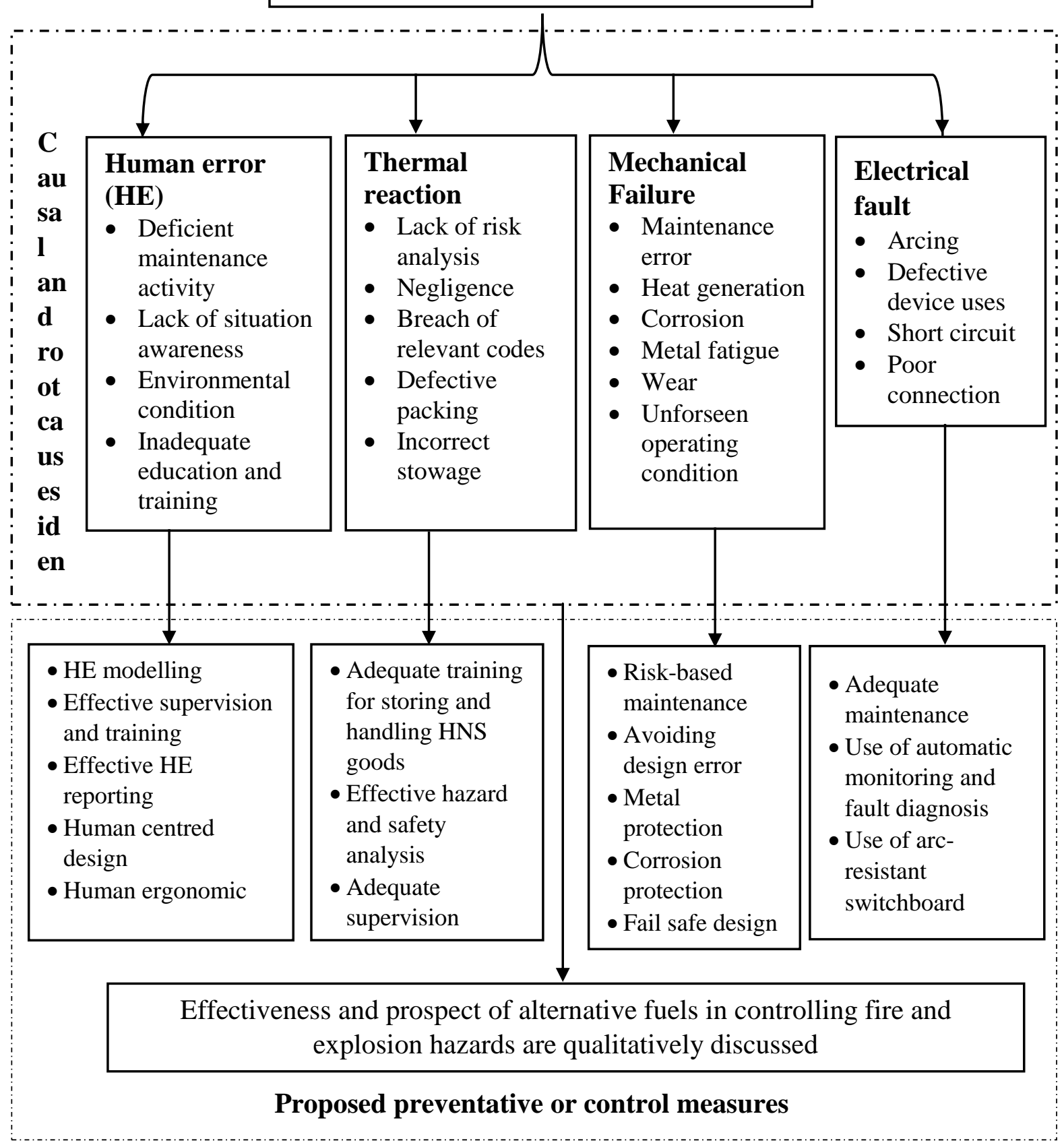

Figure 3. Steps undertaken in this study

43 causes, contributing factors that were responsible for past fire and explosion accidents in

144 shipping are considered. This can provide different real scenarios of fire and explosion events

145 and help identify real causes and their potential mitigation approaches. An overview of steps

146 undertaken in this study is given in Figure 3. This shows that the four causal factors and 
several underlying causes of fire and explosion accidents are identified using past accidents

information and that general preventative measures are proposed qualitatively.

\subsection{Human error as a cause of fire and explosion accidents}

The American Bureau of Shipping (ABS) (2003) report stated that marine accidents

151 directly associated with human errors in the MAIB, the ATSB, and the TSB reports total $82 \%$, $85 \%$, and $84 \%$, respectively. This confirms that there is a consistency of causal factor

findings among the data and reports in Australian, Canadian, and UK transport accident investigation authorities. This outcome has been supported by other studies (Baker and McCafferty, 2005; Rothblum, 2000; Wagenaar and Groeneweg, 1987). For instance, human error is involved in 75-96\% of marine causalities (Rothblum, 2000). A study by Wagenaar and Groeneweg (1987) showed human error contributed to a total of 96 out of 100 marine accidents. Similar results were reported in Baker and McCafferty (2005) where within the period 1991-2001, 80-85\% of the maritime accidents were due to human error, 50\% were initiated by human error and 30\% associated with human error.

Apostol-Mates and Barbu (2016), stated that human error is related to technology, environment, organisation, work practice and group. The Nippon Kaiji Kyokai - a classification society, (ClassNK, 2010) broadly divided the factors related to the occurrence of human error into human element, hardware factors, and organisation and management factors. Baker and McCafferty (2005) categorised them into five broad groups including situation awareness group, management group, risk group, maintenance human errors and non-human error group and argued that failure of situation awareness and assessment, resulting from human fatigue and task omission, is predominant. Whittingham (2004) 169 postulated two types of human error causation namely internal causes leading to endogenous 170 error and external causes leading to exogenous error. An endogenous error relates to an 171 internal cause arising from an individual such as a failure within the cognitive processes. An 
exogenous error has an external cause such as an unsuitable working environment. Reason (2000) discussed human fallibility using two approaches: the person and the system approaches. The person approach is related to errors of individuals, blaming workers for unsafe acts such negligence, forgetfulness, inattention, or moral weakness. The system approach focuses on the existing errors in the workplace and the organisational processes. Based on this concept, human failure is grouped into two categories namely active failures and latent failures. The active failures are the unsafe acts committed by frontline people such as drivers, control room staff or machine operators. The unsafe acts include a variety of practices such as slip ups, lapses, fumbles, mistakes, and procedural violations. The latent failures arise from decisions made by designers, builders, procedure writers, and top level management. Examples of latent failures are poor design of plant and equipment, ineffective training, inadequate supervision, ineffective communications, and uncertainties in roles and responsibilities. Latent failures often remain dormant within the system before they combine with active failures and local triggers to create an accident scenario. These failures can be identified and remedied before an adverse event occurs using proactive risk management strategy (Reason, 2000).

Rothblum (2000) stated that the maritime system is a people system where people interact with technology, environment, and organizational factors. Humans may not be the sole cause of an accident and in most accidents are involved in a complex interaction of several factors such as software, hardware, environmental conditions and other humans (Shappell and Wiegmann, 1997). Human interaction with other key factors is shown in Figure 4. This shows that human factor depends on individual factors such as competency, health, stress and strength, workplace environment (such as site design, ease of use and working condition) and management (procedures, supervision and communications) under which he or she works. 
WORKPLACES

Workplace factors

Site design, fixed plant design, geotech design, access, etc.

\section{Equipment design}

Displays, controls, interface, feedback, warning systems, ease of use

\section{Work environment}

Noise, vibration, visibility, temperature, chemical exposure, dust etc.

\section{PEOPLE}

\section{Individual factors}

Knowledge, competency, expectation, attention, goals, health, fatigue, age, body size, strength, stress, etc

198 Figure 4. Human interaction with other factors (WORKSAFE BC, 2017)

199 In order to identify underlying causes of human failures, generic human error was

200 functionally deconstructed into logical, mutually exclusive categories into skill based, rule

201 based, and knowledge based errors, routine violations and singular violation as shown in

202 Figure 5.

\section{MANAGEMENT}

Resourcing, organisation of work, policies, procedures, management Job design

Rosters, workload, task design, supervision, etc.

\section{Information transfer}

Communication (written and oral), handovers, instructions, labels, signs, etc. 


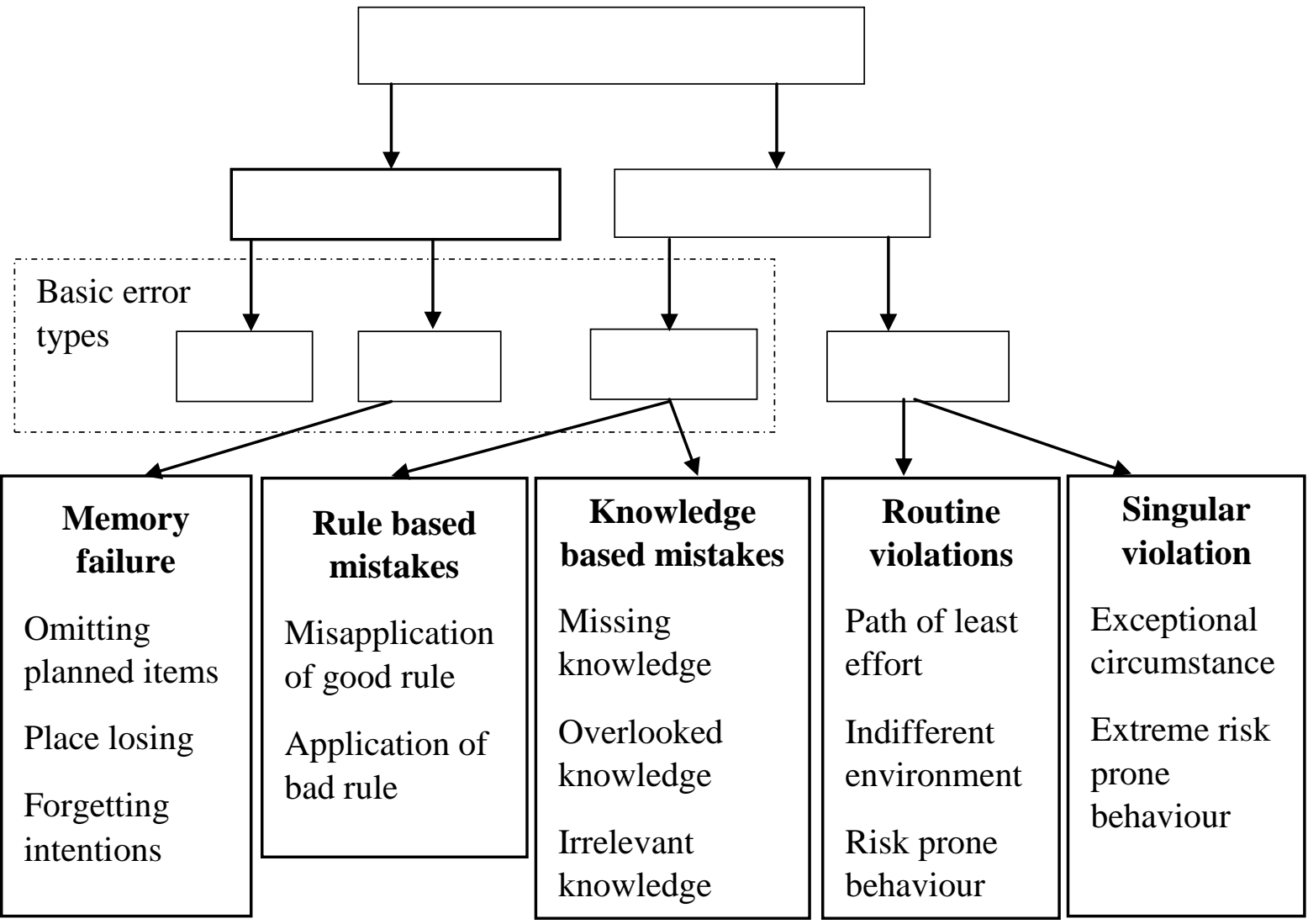

204 Figure 5. Behavioural deconstruction of human error (Harrald et al., 1998).

213 Table 1. Contributing factors of human error on shipping accident

$$
\text { Acts (level 1) }
$$

Supervision (level

Organisational influences (level 4) 
1. Errors

a. Skill-based errors

b. Judgment and decision making errors

c. Misperception errors

2. Violations

2. Individuals condition

a. Adverse physiological states

b. Physical mental limitations

c. Perceptual factors
1. Inadequate

supervision

1. Resource
a. Physical environmental

b. Technological environmental

c. Cognitive factors

d. Psycho behavioural factors
2. Inappropriate operation

3. Failed to correct problem

4. Supervisory violations management

2. Organisational climate

3. Organisation process

\section{Personnel factors}

a. Coordination/ communication/ planning factors

b. Self-imposed stress

Among several causes of human error, deficient maintenance is one of the major

215 causes of fire and explosion (Okoh and Haugen, 2014). This includes inadequate hazard

216 analysis, violation of hot work and confined space entry permit guidelines. Some major

217 accidents include an explosion and fire on the tanker Petrolab (TSB, 1999), boiler explosions

218 on the bulk carrier Shirane (ATSB, 2007a) and cargo hold fire on BBC Baltic (ATSB, 2012a).

219 Dhillon and Liu (2006) reviewed human error in maintenance and concluded that human

220 error in maintenance was a pressing problem. Chang and Lin (2006) reviewed 242 accidents

221 that occurred between 1960-2003 in storage tanks and revealed that fire and explosion

222 accounted for $85 \%$ of these accidents and $30 \%$ of accidents were caused by human errors 
including poor operation and maintenance. Okoh and Haugen (2013) stated that about 30-40\%

of all accidents and precursor events in the chemical processing industry are due to

maintenance-related factors. In another study conducted by Okoh and Haugen (2014)

revealed that among 80 maintenance related major accidents, explosion was involved in $44 \%$ of these accidents followed by fire (34\%). Hemmatian et al. (2014) also revealed that human error occurred mostly in general maintenance activities. In the current study, maintenance related errors were observed in $43 \%$ of human error accidents. The fire and explosion on the chemical tanker Bow Mariner in the Atlantic Ocean can be considered as an example of a major accident due to human error in a maintenance related activity. The accident occurred during the cleaning of residual Methyl Tert Butyl Ether (MTBE) by the crew. The accident caused 21 losses of life and the release of a large amount of MTBE, Ethyl Alcohol, heavy fuel oil and diesel into the environment (Manuel, 2011). Use of unskilled crew and lack of situation awareness was reported to be the cause of the accident (US Coast Guard, 2004). Another accident was the explosion of the Tanker Qian Chi in 2011 that led to the serious injury of three crew and caused severe damage to equipment (ATSB, 2012b). The improper installation of the thermal oil heater burner nozzle was reported to be the cause of this accident. Consequently, the fuel found its way to the burner and accumulated before the start of ignition. The furnace exploded when the igniter started. The IIWG report (Maritime Safety Committee $81^{\text {st }}$ session, 2006) stated that the majority of incidents involved MARPOL Annex II substances (rather than oil) and were caused by tank cleaning, venting or gas freeing. Celik and Cebi (2009) HFACS investigated human errors in shipping accidents and argued that disorganisation in maintenance planning and management processes are significant factors in contributing to human error. Okoh and Haugen (2014) discussed failure scenarios associated with maintenance activities and argued that lack of barrier maintenance, deficient design, organization and resource management and deficient planning/scheduling/fault diagnosis are 
the most frequent causes in terms of the active accident process, the latent accident process and the work process respectively. Deficient maintenance work also introduces new hazards particularly in safety-critical maintenance works and these are generated by application of new, invalidated procedures, processes, conditions and equipment or existing under validated ones. For example, an explosion and fire occurred in the Partridge-Raleigh oilfield in 2006 during welding of an open-ended piping left unisolated after a previous maintenance session (US Chemical Safety and Hazard Investigation Board, 2007).

Another factor responsible for human error is environmental conditions. Substandard physical working conditions may deter the effective performance of duties, causing stress and fatigue. One example of poor working conditions includes physical exhaustion due to high temperatures. High sea states, vibration, noises, and unsuitable temperature can also affect one's ability to work and can cause stress and fatigue. The environment refers not only to weather and other aspects of the physical work environment, but also the regulatory and economic climates (Rothblum, 2000). Moreover, tight economic conditions may increase the probability of risk-taking and may put enormous pressure on one's working conditions.

Ambient environmental considerations also include appropriate design of living spaces that assist in recovery from fatigue.

Every human error may lead to a condition necessary for an accident to occur which means that if there is no human error, a chain of events may break and the accident may not transpire. Hence, by employing appropriate means of preventing some human errors or increasing their detection probability in marine applications, one may provide a higher level of marine safety with fewer number of casualties (Rothblum, 2000).

\subsection{Mechanical failure as a cause of fire and explosion accidents}

Fire and explosion accidents initiated by mechanical failures have resulted in catastrophic consequences in the past. According to the Allianz Global Corporate and 
Specialty (2017) report, mechanical failure was the fifth highest reason for ship losses from

2007 to 2016. Darbra and Casal (2004) revealed that mechanical failure is the second highest grounds for general accidents followed by impacts. Vilchez et al. (1995) revealed that mechanical failures contributed $33 \%$ of accidents in a survey of 5325 accidents involving 277 hazardous materials. The VVT research (Hakkarainen et al., 2009), found that fire and 278 explosion events occurring in machinery spaces, cargo spaces and accommodation spaces of ships are $79 \%, 16 \%$ and $11 \%$ respectively. The influencing factors for mechanical failures (damage to mechanical equipment) are improperly selected material or its aging, extreme conditions of device operation, lack or malfunction of safety devices, bad quality of prepared safety mechanisms, connections or materials, spill of fuel or working fluids, and human error (improper use of tools or machines, negligence of maintenance work, and noncompliance with safety rules) (Bejger and Drzewieniecki, 2015). Similarly, Maleque and Salit (2013a) outlined that common causes of mechanical failure in a component or system are misuse, assembly errors, manufacturing defects, improper or inadequate maintenance, design errors/deficiencies, improper material or poor selection of materials, improper heat treatments, unforeseen operating conditions, inadequate quality assurance, inadequate environmental protection/control and casting discontinuities.

It is crucial to investigate the most vulnerable areas of any vessel or ship for mechanical failures. Studies of shipping accidents have shown that in most cases the fire originated in the engine room and was caused by oil or fuel coming into contact with hot exhausts. According to a research conducted by Det Norske Veritas (DNV) of 165 fires on board the DNV fleet from 1992 to 1997, 63\% of fires occurred in the engine room and 56\% of all engine room fires were caused by the combination of oil leakage onto a hot surface (Det Norske Veritas, 2000). Paula et al. (1998) presented the analysis of events involving fire and explosion from the database developed and maintained by Lloyd's Maritime Information 
298 Services Limited (LMIS) and found that the majority of fires or explosions are triggered by

299 mechanical failures due to release of fuel oil and/or lube oil system onto hot surfaces in the

300 engine room. This shows that spraying of fuel oil or lube oil on hot surfaces is one of the

301 major causes of fire on board ships. The sources of oil or fuel leakage include damaged

302 flexible hoses, couplings, piston ring, filters and fractured pipes (Det Norske Veritas, 2000).

303 In several past shipping accidents, various factors have caused mechanical failures

304 and resulted in fires and/or explosions (ATSB, 2010; MAIB, 2007); NTSB (2013). For

305 instance, on $10^{\text {th }}$ March 2012, a roll on/roll off vehicle carrier, Alliance Norfolk, encountered 306 rough weather resulting in damaged cargo and subsequent fire. The NTSB (2013) determined 307 the probable cause of the fire to be due to ignition of flammable material by an undetermined 308 ignition source due to shifting cargo while the vessel was rolling in heavy seas after losing 309 power.

310 Another factor responsible for mechanical failure is that of an unsafe act such as

311 failure to use the correct tool and procedure, negligence and inadequate supervision. For 312 example on $10^{\text {th }}$ December 2009, the containership Maersk Duffield in Moreton Bay, 313 Queensland, Australia caught fire in an engine room. The ATSB investigation (ATSB, 2010) 314 found that one or more of the connecting rod palm nuts or counterweight nuts had not been 315 tightened sufficiently during recent overhauls and that the resultant failure of one of the 316 retaining studs was the initiator of the catastrophic engine failure. Similarly, a fire broke out 317 in the auxiliary engine room on board the containership Gunde Maersk on $8^{\text {th }}$ December 2015. 318 The NTSB (2015) determined that the fire was caused by fuel leaking from a dislodged O319 ring in the fuel supply line and spraying onto the exhaust side of the engine. The leak 320 occurred because the fitting had not been tightened with a torque wrench as prescribed in the 321 manufacturer's written procedures. Likewise, on $13^{\text {th }}$ of July 2014, the bulk carrier Marigold 322 caught fire while loading a cargo of iron ore in Port Hedland, Western Australia. The ATSB 
323 (2016a) determined that the fire began on one of the generators after one of its fuel oil pipe

fittings failed, resulting in sprays of fuel oil onto a hot surface on the generator. The investigation found that the compression fitting that failed had been used to connect a replacement pressure gauge that had a different pipe connection fitting size to that of the original pressure gauge. It is evident that human factor is one of the major contributing factors for mechanical failures that lead to fire and explosion in marine vessels.

Use of damaged filter or mechanical seals has been seen as another contributing factor for mechanical failure. For instance, on $19^{\text {th }}$ of March 1999, the Multitank Ascania caught

fire due to thermal oil leaking from a thermal oil pump mechanical seal and/or a nearby flange joint onto a pressure relief valve (MAIB, 2000). Similarly, on $11^{\text {th }}$ March 1993, the oil tanker Irving Nordic experienced a main engine crankcase explosion due to piston ring failure contributed to by substantial wear on the cylinder liners and the ignition of lubricating oil (TSB, 1995).

Several mechanical failures occurred due to inadequate maintenances such as failure to follow procedure, inadequate inspection and deficient risk assessment during maintenance. For example, on $3^{\text {rd }}$ February 1995, the Norwegian flagged containership Team Heina caught fire in the engine room due to a spray of hot fuel oil, from a failed compression fitting, onto the fuel rail of the starboard generator engine which was then ignited by the hot exhaust manifold (ATSB, 1995). The ATSB investigation found that the compression fitting failed due to prolonged fretting of the pipe caused by misalignment of the pipe with the fitting and also engine vibration. Similarly, on $9^{\text {th }}$ of February 2007, the Bahamas registered general cargo ship Baltimar Boreas, whilst off Newcastle, New South Wales, caught fire in the engine room due to diesel oil spraying from a failed flexible fuel hose onto the very hot surface of the generator's engine (ATSB, 2008). The investigation found that some hoses were in poor condition and the manufacturer's instruction book and the vessel's safety 
management system provided no guidance for the maintenance or routine replacement of the

flexible hoses. On $24^{\text {th }}$ August 1998, the containership Repulse Bay caught fire in the engine room. The fire was caused by ignition of oil leaked from fractured bolts of the exhaust valve actuator (MAIB, 1999). The bolts fractured due to cyclic loads and fatigue and investigation found that there were no engine manufacturer's guidelines for maintenance or inspection.

Beside these aforementioned factors, there are other factors responsible for 


\subsection{Thermal reaction as a cause of fire and explosion accidents}

In the shipping industry, reaction or auto-ignition of loaded Hazardous and Noxious

Substances (HNS) is a contributing factor for some fire and explosion accidents. According

to Munich Re Group (2002) report, container vessels can sometimes carry as much as $10-40 \%$

volume of hazardous goods. Violent reactions may occur when incompatible chemicals are mixed (Baltic Marine Environment Protection Commission (HELCOM), 2002). Chemical accidents originating from improper storage make up almost $25 \%$ of all chemical accidents

(U.S. Chemical Safety and Hazard Investigation Board, 2002).

In order to avoid potential hazards while mixing or storing chemicals, the guidelines mostly used are from US Environmental Protection Agency's Chemical Compatibility Chart (Hatayama et al., 1980), U.S. Coast Guard's Cargo Compatibility Chart and Chemical Hazards Response Information System (CHRIS) (US Coast Guard, 1980) and National Oceanic and Atmospheric Administration's Chemical Reactivity Worksheet (Simmons et al., 2008). Shippers of dangerous goods on board ship are required to pack and mark the goods in accordance with the International Maritime Dangerous Goods (IMDG) Code (Ozcayir, 2007) and to provide necessary shipping documents and declaration that the dangerous goods are in all respects in proper condition for carriage (ATSB, 2007b).

Despite these guidelines and application of codes, fire and explosion has been reported while shipping dangerous and noxious goods due to chemical reactions or autoignition of goods (BSU, 2014; Sam, 2012; Schröder and Prause, 2016). Dangerous and noxious goods on board a ship increase the likelihood and consequences of fire and explosion accidents (Schuda, 1991). This has been supported by some major fire and explosion accidents involving goods carried on board container ships globally (ATSB, 2007b; Ellis, 2011; Haveman and Shatz, 2006). For instance, on $21^{\text {st }}$ March 2006, an explosion and fire on board the container ship Hyundai Fortune in the Indian Ocean compelled the crew to abandon 
the vessel and it resulted in total constructive loss (Ellis, 2011; Sam, 2012). It is suspected and alleged that natural ignition of dangerous goods such as calcium hypochlorite or fireworks may have caused the initial explosions due to ambient temperatures and improper stowage (ATSB, 2007b; Ellis, 2011). Similarly, on $11^{\text {th }}$ November 2002, the container ship Hanjin Pennsylvania, suffered a fire and explosion in the Indian Ocean with the loss of two lives. This was caused by undeclared dangerous goods, magnesium (Ellis, 2010). These incidents indicate the consequences of undeclared goods in shipping.

The main contributing factors for reaction or auto-ignition of loaded goods are defective packaging and incorrect stowage. The root causes of these are difficulty in chemical hazard identification and human error because of the complex nature of chemistry and the multitude of chemical regulations and their organisations relevant to their packing, storage and shipping (Simmons et al., 2009). Some chemicals such as methyl ethyl ketone peroxide (MEKP) are unstable and extremely flammable at ambient conditions. They readily cause fire and explosions if they are neither stored nor handled appropriately $(2008 \mathrm{a} ; 2008 \mathrm{~b})$. On $7^{\text {th }}$ July 2010, a container ship, Charlotte Maersk, caught fire while en route from Port Klang, Malaysia bound for Salalah, Oman. Based on circumstantial evidence, the DMAIB (2012) pointed out that the fire probably originated from the container containing methyl ethyl ketone peroxide (MEKP).

Some chemicals such as calcium hypochlorite are prone to thermal runaway, a phenomenon in which the heat naturally produced by the chemical serves to heat itself further, thus generating more heat (Barton and Nolan, 1989; Clancey, 1987). According to the United States Court of Appeals for the Second Circuit ruling for the M/V DG Harmony explosion (2008c), on $9^{\text {th }}$ November 1998 , the ship was carrying approximately 160,000 kilograms of calcium hypochlorite below deck when an explosion occurred in the area where the calcium hypochlorite was being stored. Another explosion occurred on the vessel Contship France in 
October 1997, while the ship was carrying 512 drums of calcium hypochlorite (Tamburello, 2011). The explosion was caused by the self-heating of calcium hypochlorite contained in the area of the explosion. The United States Court of Appeals for the Second Circuit (2006) acknowledged that temperatures in the cargo area were high enough for the calcium hypochlorite to spontaneously ignite and recognised it as the cause of the explosion.

Additionally, defective packaging, such as loose lids on steel drums and loosely tied or damaged bulky bags can expose HNS goods to hazardous conditions and transporting them in large packages, such as bulky bags, increases the risk of auto-ignition and

flammability (National Industrial Chemicals Notification and Assessment Scheme (NICNAS), 1995). Defective packaging and incorrect stowage are directly related to human and organisational errors. For example, on $14^{\text {th }}$ July 2012, the German-flagged full container ship MSC Flaminia caught fire and exploded. The BSU (2014) stated, after analysing the physical and chemical properties of all the items of cargo in cargo hatch 4 of the damaged container, the most likely cause of the fire was either a release of car care products or leakage of dimethylaminoethanol from a tank container, which in turn reacted with surrounding items of cargo generating heat and ignition. In February 2007, the Nitrogen, Phosphorous and Potassium (NPK) fertilizer aboard the cargo ship Ostedijk underwent a chemical reaction and destroyed part of the cargo and compromised the ship (Babrauskas, 2003). This chemical is known to undergo self-sustaining decomposition reactions upon exposure to a heat source (Babrauskas, 2003).

Past shipping accidents confirm that the root causes of chemical reactions that lead to fire and explosion are mainly thermal runaway, auto-ignition and leakage due to defective packaging and incorrect stowage preceded by human and organisational errors, and inadequate safety analysis. This indicates that despite availability of regulatory requirements, databases/tables, codes and signage for chemical storage and handling, thermal reaction is 
still a major contributing factor to accidents in shipping. This demands a need for detailed study of properties of chemicals and the precautions that should be taken to avoid devastating losses.

\subsection{Electric fault as a cause of fire and explosion accidents}

Faults in electrical systems can be classified into a few groups such as poor electrical connections, short or open circuits, overloads, load imbalance and improper equipment installation (Jadin and Taib, 2012). Most commonly, an electrical fault on a ship causes three types of incident, being electrical shock, electrical fires and electrical failures. Electrical fire is a serious hazard aboard any ship and is most likely caused by faulty or improperly maintained electrical equipment. Electrical faults or malfunctions have resulted in several residential, industrial and shipping accidents in the past (Ahrens, 2016; ATSB, 2016b;

Campbell, 2016). The National Fire Protection Association research report (Campbell, 2017) described electrical fires based on type of device that failed, type of malfunctions, location and origin, and time of occurrence. This report shows that electrical distribution, lighting and power transfer contributed to $57 \%$ of reported home fires involving electrical failure or malfunction. Babrauskas (2008) described electrical fires by grouping them into two categories, namely (1) according to the nature of the physical mechanism that led to ignition, and (2) according to causative factors which caused the failure mechanism to be triggered. Babrauskas (2008) stated that physical mechanisms causing electrical fires are poor connections, arcing across a carbonised path, arcing in air, excessive thermal insulation, overload, ejection of hot particles, dielectric breakdown in solid or liquid insulators and miscellaneous phenomena. The US Consumer Product Safety Commission (CPSC) study (1990) outlined the causative factors for electrical fire as improper altercations, improper initial installation, deterioration due to aging, improper use, inadequate capacity, faulty product and unknown. The study found that improper altercations contributed to $37 \%$ of the 
reported residential electrical distribution system fires. Fires on ships are caused by electrical faults, ignition of spilled oils and fuels (Mouritz and Mathys, 1999). A research project on 165 fires on board the DNV fleet from 1992 to 1997 found that $9 \%$ of fires originated from electrical components (Det Norske Veritas, 2000).

Electrical faults or malfunctions have caused a number of fire accidents on marine vessels. For instance, on December $11^{\text {th }}, 2015$ a fire broke out in the electrical control room aboard the freighter Alpena 2015 and resulted in damage costs of 4 million dollars (Stuards, 2015). The NTSB (2016) determined that the probable cause of the fire was a fault in the electrical wiring providing power to the aft anchor winch.

In some fire and explosion accidents that occurred on shipping vessels, investigations could not conclusively find actual causes of accidents and thus, only provided likely or possible causes based on circumstances. For instance, on $28^{\text {th }}$ April 1990, Val Rosandra was discharging refrigerated propylene at Brindisi in Italy when a violent explosion occurred in the cargo compressor motor room with a consequent fire due to ignition of escaping propylene. It is believed that the explosion most likely occurred because of ignition of released gas with electrical equipment in the compressor motor room (Niall and Roger, 2002). Similarly, on $7^{\text {th }}$ August 1997, a fire was discovered on the lower bridge deck of the Taiwanese flag bulk carrier Ming Mercy. Based on circumstantial evidence such as the remainder of amateur wiring extensions found in the location of fire and other accommodation spaces, the source of the fire was identified as electrical fault (Marine Incident Investigation Unit, 1997).

On $9^{\text {th }}$ of October 2014, a fire started in crew cabin 4 located on the upper deck of Ocean Drover's accommodation block. The investigations (ATSB, 2016b) could not identify the exact origin or cause of the fire because of loss of physical evidence. However, it was stated that electrical sources or smoking-related activities were likely origins of the fire. On 
$1^{\text {st }}$ May 2013, heat and smoke were detected on the Swedish-flagged con-ro carrier Atlantic

Cartier and the fire spread rapidly, resulting in cargo and material damages, i.e. cable routing beneath the ceiling and deck deformation (BSU, 2015). Due to preceding extinguishing works, smoke build up and the prolonged period of the fire, traces of evidences about the causes of the fire that might had been presented originally, were covered or destroyed, thus precise causes could not be identified. Based on circumstantial evidence, the BSU Report $99 / 13$ stated that there were a number of conceivable causes, including a technical fault in the electrical system of a vehicle due to an overload or short circuit and partial overheating. Additional possible conceivable causes included negligent or malicious arson, inadequate wiring revealed by cable loops protruding from the protective sheath, traces of corrosion on cables, cable connections of inconsistent strength, existing damage to cables due to welding operations, damage due to abrasion caused by metal cables, forcibly bent cables inside the insulation, damage to the insulation due to overheating and traces of several earlier fires on deck 3 B.

Investigation of fire accidents can be complex and not as clear cut as other forms of investigation (Beland, 1984a; Hine, 2004). This is due to the possibility of omission of traces of evidence because of extinguishing works, smoke build-up, prolonged burning or fire damage, and the complex nature of fire scenarios. Beland (1984b) claimed that electricity is not as fire prone as generally believed and concluded that electrical fires are conceivable when different abuses such as overloading, combustible materials, high ambient temperatures and inadequate insulation are present. Due to the complexity involved in the justification of actual causes of fire or lack of precise physical evidence, a significant number of fires were mis-investigated and were assigned as electrical fires (Babrauskas, 2001; Beland, 1984b; Béland, 1992). Beland (1984b) further argued that electricity is a handy scapegoat because it is often difficult to defend it and electricity, as the cause of fire, is also defended on 
unconvincing evidence that electrical equipment was close to the point of origin. This later claim is not ruled out if the investigation reports of Atlantic Cartier fire, Ocean Drover fire and Val Rosandra fire and explosion accidents are referred to because their concluding remarks about cause of fire were all based on circumstantial evidence.

Despite such claims, there exists much evidence clearly justifying that electricity has contributed to fire and explosion accidents causing catastrophic consequences in residential, industrial and commercial spaces (Babrauskas, 2001; Campbell, 2016; Daeid, 2004;

Troitzsch, 2016). This signifies a need for systematic research and investigation approaches in regard to causes of fires and explosions in order to improve accident investigations and to reduce fire and explosion accident losses.

In this study, it is found that about $9 \%$ fire and explosion accidents have unknown 532 causes or definite contributing factors, and their underlying causes were not identified during investigation. Most physical evidence leading to fire and explosion is often damaged and destroyed during the accident (Beland, 1984a; Hine, 2004). This shows that investigation of fire and explosion accidents requires special attention and may need more effective approaches.

\section{Preventative measures of fire and explosion accidents}

The causal factors of fire and explosion accidents can be avoided or mitigated by adopting preventative measures. In order to prevent or mitigate the causes, identification of potential preventative measures is important. However, there is no silver bullet to identify solutions to all contributing factors. Due to this, some potential preventative measures are given in generic ways for each contributing factor.

\subsection{Prevention and mitigation of human error}

Humans are generally seen as error-prone as proved by numerous examples of human error. This signifies a need for design of human independent systems by replacing human 
performance with technology, specifically by automation, which is considered highly reliable 4 5548 6

547 because it is the result of a formal design process and is based on components with known

548 failure rates (Hollnagel, 2008). Moreover, employing human centred approach may be

549 effective to mitigate human error because it puts the human user at the centre of the design as 550 shown in Figure 6 (Midland Engineering, 2017).

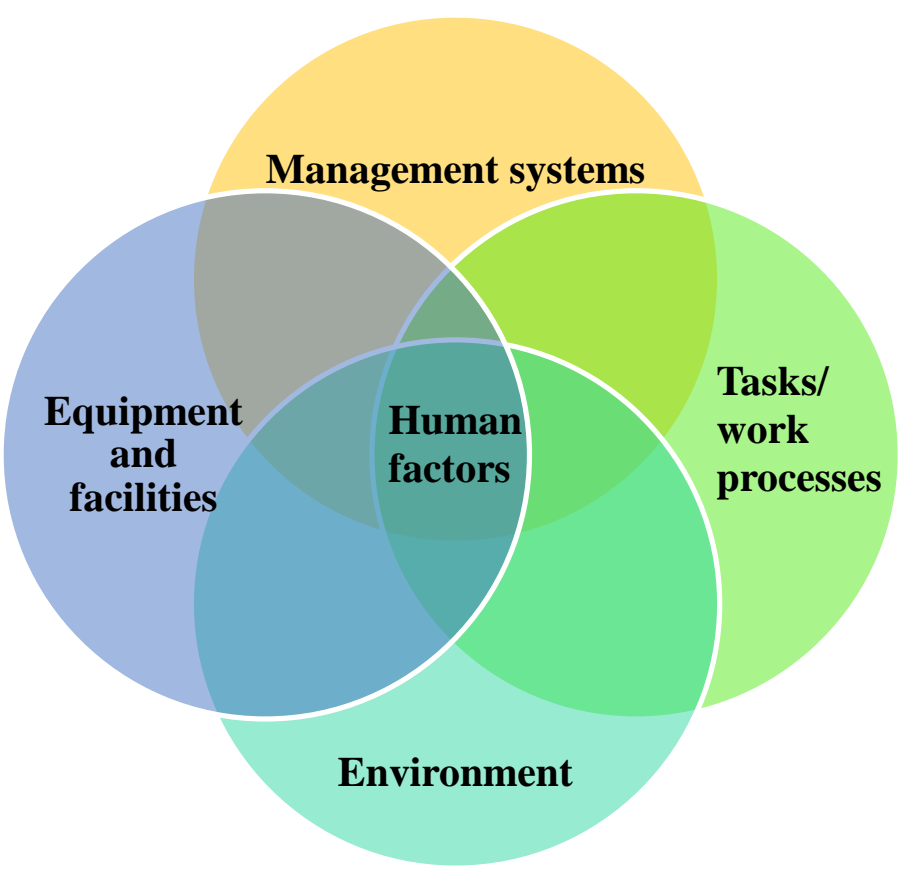

552 Figure 6. Human centred approach for mitigating human error (Midland Engineering, 2017)

553 In marine operations, human errors that lead to fire and or explosion generally occur 554 in maintenance activities. In this study, it is found that $43 \%$ of human error results from 555 maintenance related activities such as hot work, overhauls and inspections. Maintenance has 556 been a subject of major interest in order to avoid or reduce human error. Pennie et al. (2007) 557 introduced the issue of maintenance error considering the human factor in maritime 558 maintenance and inspection and with emphasis on design for maintainability. Islam et al. 559 (2016) determined human error probabilities in maintenance operations of marine engines 
and argued that the checking of fuel and lubricating oil filter pressure difference activity have high probability for accidents.

For human error likelihood assessments, different approaches such as the Human 563 Error Assessment and Reduction Technique (HEART), the Technique for Human Error Rate 564 Prediction (THERP) and the Success Likelihood Index Method (SLIM) are used (Abbassi et 565 al., 2015; Noroozi et al., 2010). Islam et al. (2017) developed a monograph for assessing the 566 likelihood of human error in marine operations and argued that the monograph can 567 significantly decrease the time and resources required to estimate Human Error Probability 568 (HEP) when decision making for marine operations involving different environmental and 569 operational conditions. Applications of these methodologies can be helpful tools to reduce the 570 potential of accident occurrence by assessing HEP.

$571 \quad$ Human error modelling (HEM) and an adoption of 'open culture' or confidential 572 reporting system (CRS) are essential to better understand the causes and effects of human 573 error (Whittingham, 2004). The HEM helps to explore the relationship between task and error, 574 and helps to better understand the role of human error in accident sequences. Adoption of 575 open culture encourages employees to report errors that they have made, or seen, so that the 576 underlying causes can be investigated and corrected on time. A CRS enables error or other 577 safety issues to be reported confidentially (without fear of litigation) by an employee to a 578 concerned authority and the authority then communicates the information to the employer for 579 necessary action (O'Leary and Chappell, 1996).

580 In most cases, human errors are caused by the growing imbalance between system 581 reliability and human reliability. In order to overcome this imbalance, the science of 582 ergonomics has evolved which focuses on addressing how the design of the interface between 583 human and machine could take more account of human capabilities and maximize human 584 performance thereby reducing the probability of human error (Karwowski, 2012). This helps 
to prevent human actions becoming out-of-tolerance in terms of exceeding some limit of acceptability for a desired system function (Whittingham, 2004).

According to Karwowski (2005), the current focus of the human factors and ergonomics (HFE) discipline is on the design and management of systems that satisfy human compatibility requirements. The design integration refers to interactions between hardware (computer-based technology), organization (organizational structure), information system and people (human skills, training and expertise). Systems' management maintains the interactions between various systems' elements across process and product quality, workplace and work system design, occupational safety and health programmes and corporate environmental protection policies. The author further emphasised that emerging branches of HFE such as microergonomics, neuro-ergonomics and nanoergonomics would play a significant role in mitigating human errors. For instance, neuro-ergonomics focuses on the neural control and brain manifestations of the perceptual-physical-cognitive-emotional interrelationships in human work activities (Parasuraman, 2003). This aims to design a workplace to better match the neural capacities and limitations of human.

The ABS (2014) proposed a Human Factors Engineering/Ergonomics Model which contains four elements that influence safety and efficiency in job performance. They are vessel or offshore installation design and layout considerations, workplace ambient environmental conditions, management and organizational issues related to operations, and 604 the personnel who operate the vessel or offshore installation as depicted in Figure 7. In order 605 to maintain safety, productivity and efficiency, sufficient attention needs to be given to these 606 elements and these elements should be at the core of any HFE implementation effort (ABS, 607 2014). 


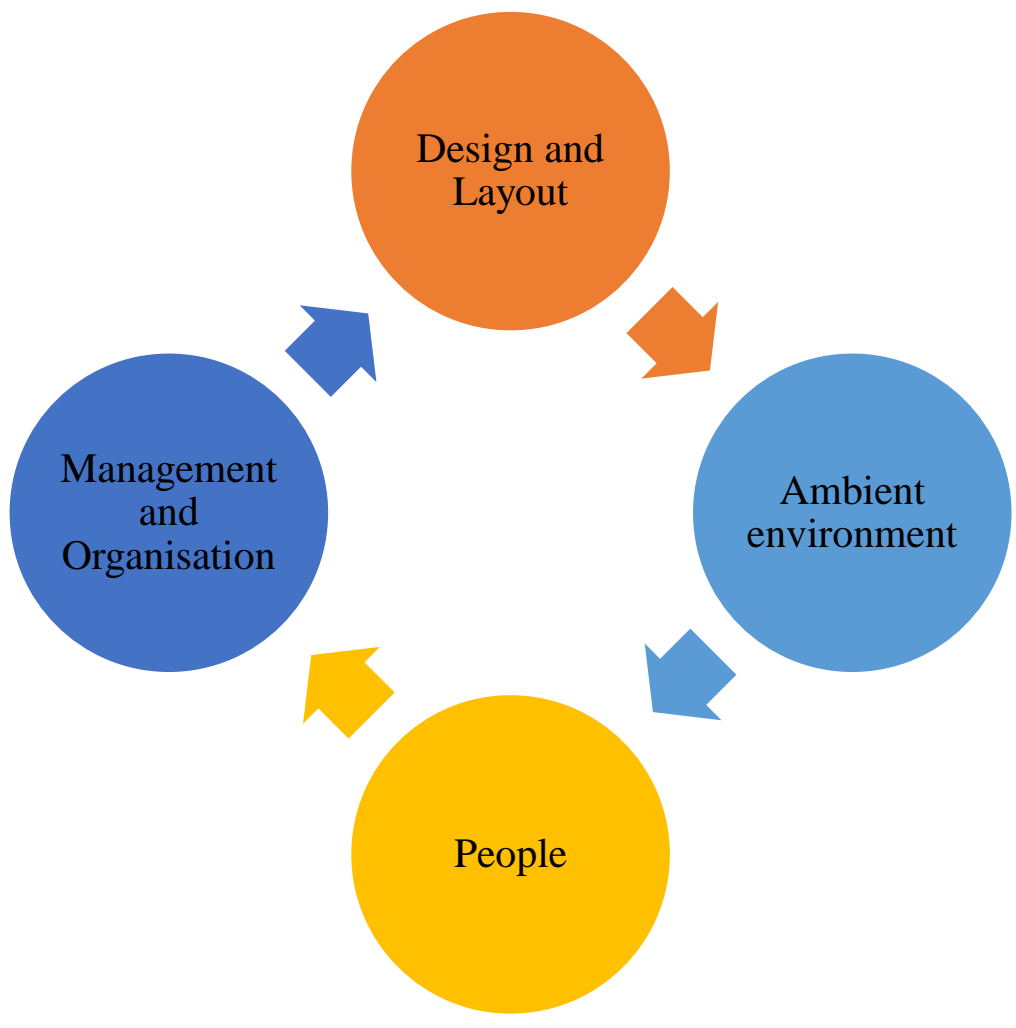

611 prevention of both active and latent human failures, it should be looked at from a system

612 approach which generally consists of defences, barriers, and safeguards. Maritime

613 transportation has many defensive layers such as those which are engineered (alarms,

614 physical barriers, automatic shutdowns, etc), people (control room operators, etc), and

615 procedures and administrative controls. For prevention of fire and explosion accidents due to

616 human factor, Swiss cheese model can be used as suggested by Reason (2000). The

617 developed Swiss cheese model has three safety layers, equipment, processes and people, with

618 direct influence of organisational safety culture as shown in Figure 8. The presence of holes

619 (errors, deficiency, flaws) in any one layer does not normally cause an accident. Usually, this

620 can happen only when the holes in all layers momentarily line up allowing the hazards to pass

621 through all layers. It is obvious that reducing the number of holes in each slice would play a

622 key role in decreasing likelihood of accidents. 

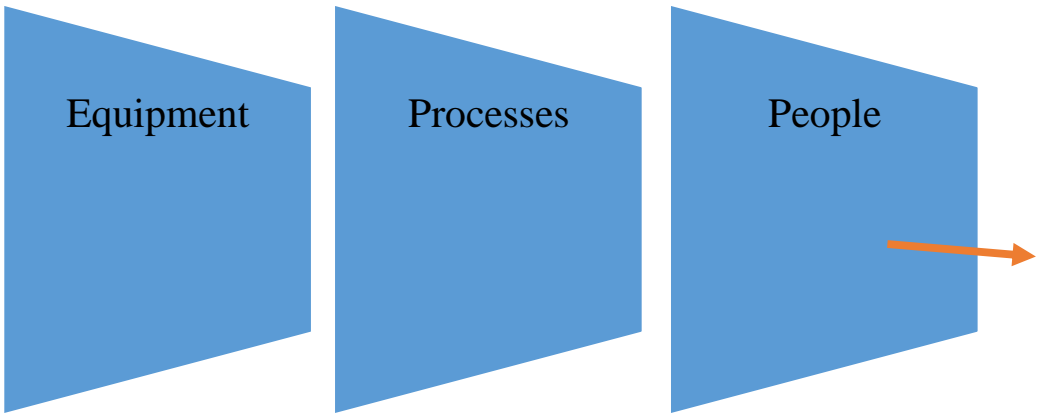

Fire and explosion hazards

Organisational safety culture<smiles>c1ccccc1</smiles><smiles>COCCO</smiles>

Accident

Figure 8. Swiss cheese model for accident prevention due to human factor

Equipment should be designed, located and modified in such a way that it contributes

in reduction of errors during use, maintenance, inspection and testing thereby incorporating

the effects of the environment in which they are operated. Workspace should be designed

suitable for high human reliability. As far as possible equipment and its accessories need to

be equipped with fire resistances and protections and flammable fluid inventories should have adequate leak prevention measures. Second safety barrier is processes which mainly comprise procedures, fire and explosion risk management, near misses and precursor's investigations, safety critical communication, staffing levels and workload. Procedures need to be clear and practical. Safety critical communications must be clear and unambiguous. Staffing levels and workloads must not compromise safety. The final barrier is people. Employees need adequate training and competence along with the correct level of supervision and leadership.

Appropriate instructions for various operations (hot work permits, inspection and 

analysis should include human failures and behavioural safety including human interactions with other factors. Organisational safety culture needs to be appropriate such that it can play a central role to organise and co-ordinate safety barriers for prevention of accidents.

\subsection{Prevention and mitigation of mechanical failure}

Mechanical failures involve an extremely complex interaction of load, time and environment (Stephens et al., 2000). The complex nature of metal failures can only be understood by identifying different types of mechanical failures such as fracture, fatigue, creep, corrosion and wear (Maleque and Salit, 2013a). Vilchez et al. (1995) identified that leaking valve, overpressure, metallurgy failure, corrosion, flange coupling failure, hose failure, overheating, weld failure, leaking gland, relief valve failure, fatigue, overload, brittle failure, incompatible material use are specific causes of mechanical failure.

The causes of fatigue failure are identified as unintended stresses, misuse, design deficiencies, incorrect assembly, and deficient testing and inspection techniques (Scutti and McBrine, 2002). In this study, fatigue failure of a component is observed in $36 \%$ of accidents in mechanical failure category. Failure due to fracture can be prevented by avoiding stress concentration, reducing the speed of loading, avoiding ductile-brittle transition temperature and preventing thermal shock (Maleque and Salit, 2013a). The most effective method to prevent fatigue failure is in design improvement by avoiding sharp surface tears, surface discontinuities and tensile residual stresses and improving fabrication and fastening procedures (Maleque and Salit, 2013b). Creep occurs when the metal, under certain loads is heated normally over $40 \%$ of melting temperature of the material (Brnic et al., 2017). An understanding of behaviour of a material at high temperature with certain load over a period of time is a useful approach. It helps in evaluating failures of components due to creep (Dasgupta and Pecht, 1991). The fatigue failure and creep can be prevented by avoiding 
unintended stresses and strains and design deficiencies and using adequate coating, defect

\section{degradation (Khan and Howard, 2007).}

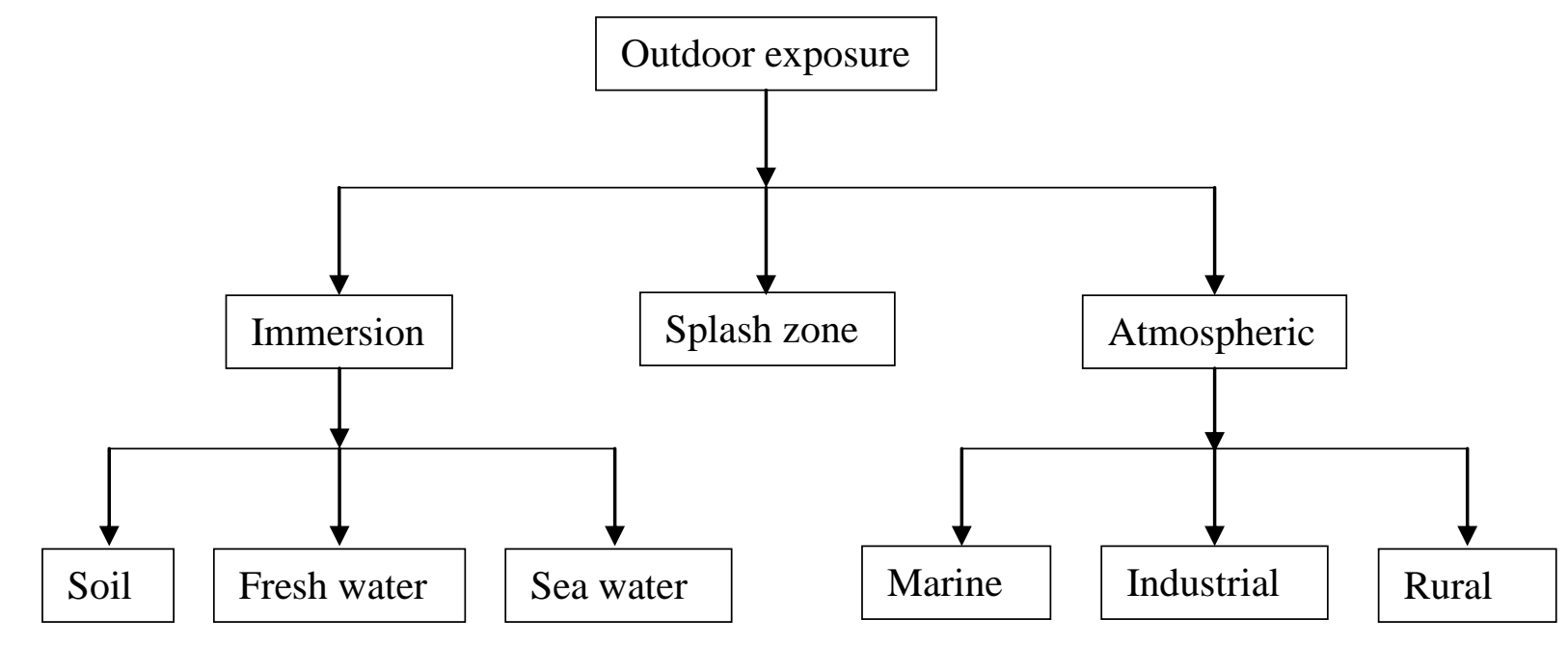$$
\text { detection and testing techniques. }
$$

Corrosion is a very widespread problem in all engineering structures, especially those in harsh chemical environments such as chemical engineering processing equipment and in salty environments (Dasgupta and Pecht, 1991). Failure, due to corrosion, can be controlled or minimised by various means, such as correct material selection, galvanic protection, corrosion inhibitors, adequate corrosion monitoring and inspection and protective coating (Nalli, 2010). The various environmental conditions usually encountered by anticorrosive coatings are given in Figure 9. In order to avoid material degradation due to corrosion, protection of anticorrosive coatings is essential. Anticorrosive coatings used in metals can be protected using barrier protection, passivation of surface (inhibitive effect) and sacrificial protection (galvanic effect) (Sørensen et al., 2009). Additionally, adoption of risk based inspection planning and integrity assessment methods may avoid failures due to material

Figure 9. Various environments encountered by anticorrosive coatings (Sørensen et al., 2009)

It is important to understand the principles of corrosion in order to effectively select materials and to design, fabricate, and utilize metal structures for the optimum economic life 
679 of facilities because no particular material is the cure for all types of corrosion (Popoola et al., 1 680 2013). To understand the principles of corrosion, modelling of corrosion has been done 4 5681 considering experimental tests and probabilistic approaches such as Bayesian Networks (BN) 8 10 


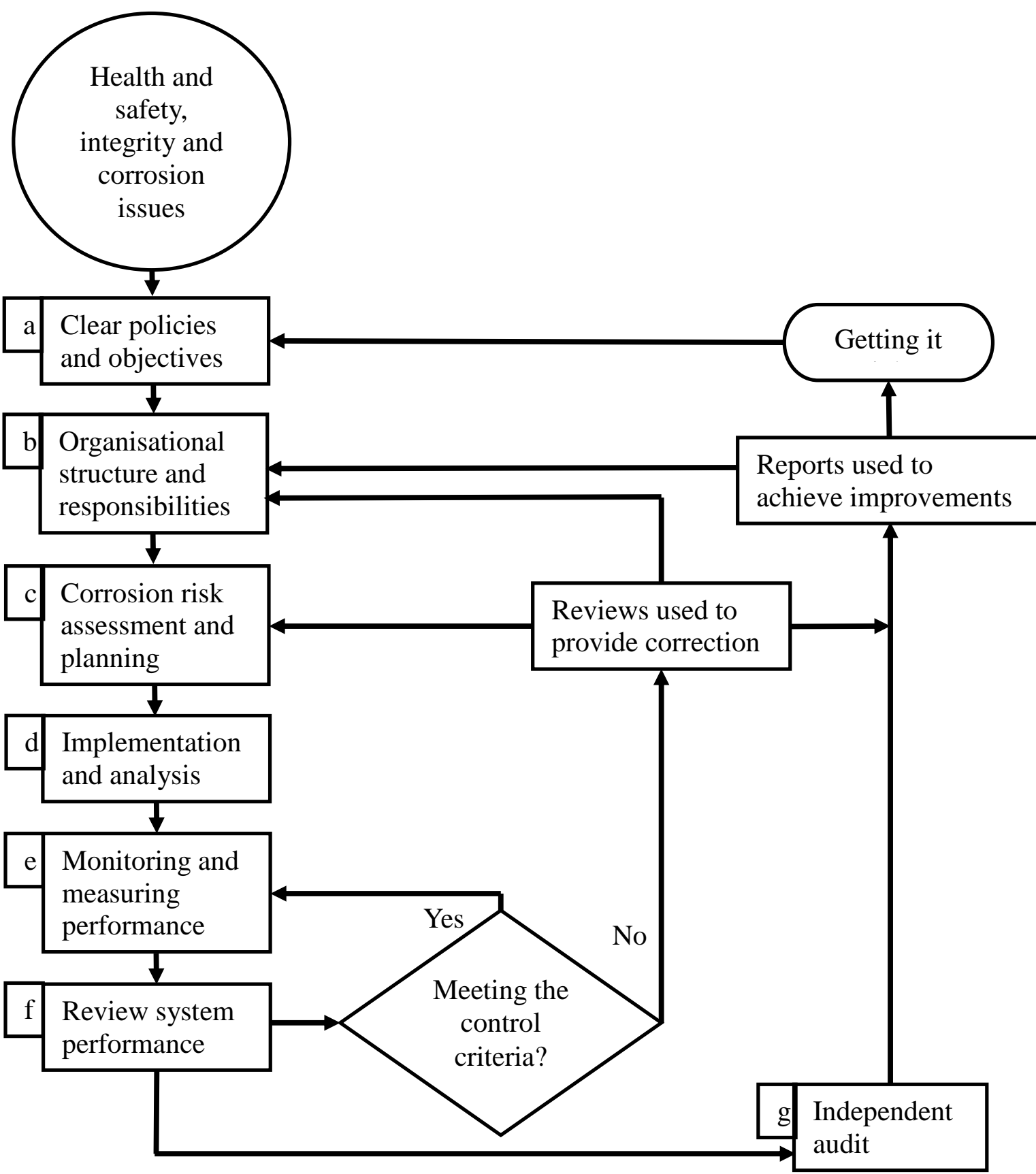

686 Figure 10. The basic corrosion management process model (Energy Institute, 2008)

687 Wear is caused by the removal or displacement of material due to mechanical action

688 of a contacting solid, liquid or gas. Failure due to wear can be controlled by preventing

689 removal of material and reduction of dimension with proper material selection and design

690 (Maleque and Salit, 2013b). Moreover, materials or parts vulnerable to wear need adequate 
maintenance and overhaul because wear cannot be totally eliminated. Therefore, the causes of

failure of engineering components can be controlled or prevented by appropriate design, better materials selection, avoiding manufacturing defects and overloading, and adequate maintenance.

\subsection{Prevention of thermal reaction in shipped goods}

The shipping industry is involved with transporting goods ranging from nonhazardous to water reactive, corrosive, toxic and highly flammable. For maintaining safety during the transportation of hazardous goods, a number of international codes, such as international maritime dangerous goods code, construction and equipment of ships carrying dangerous chemicals in bulk (resolution A212 VII), Marine pollution convention, the revised guidelines of IMCO on hazardous chemical classification and the International Convention for the Safety of Life at Sea (SOLAS) Chapter VII (Carriage of Dangerous Goods) amendments (2002), are being implemented (Rao and Raghavan, 1996). Goods that are listed within the codes must be transported according to the provisions which specify requirements for packing, consignment, and transport operations, including packaging to be used, marking, labelling, placarding, stowing, segregation, and transport documentation (Ellis, 2010).

Despite these codes and regulations, the shipping industry has experienced many fire and explosion accidents in the past, mainly because of thermal runaway, auto-ignition and leakage due to defective packaging and incorrect stowage.

Some chemicals decompose rapidly on heating and under influence of light, and react violently with incompatible substances or ignition sources (acids, bases, reducing agents and heavy metals) to cause fire and explosion hazards (Wang et al., 2009). These properties of chemicals are required to be clearly identified, and more efforts are needed for reactive, selfreactive or incompatible chemicals. For instance, Wang et al. (2009) used a preliminary calorimetry approach to identify the effect of the incompatibility on the thermal hazards of 
716 Tert-butyl hydroperoxide (TBHP) to understand the safe design and precaution for the

717 hazards of incompatibility of TBHP. The study found that TBHP solutions with alkaline have

718 potential thermal instability and the aqueous TBHP can show more severe thermal and self-

719 reactive hazards in the presence of contaminants. Hence, care should be taken in shipping,

720 handling and storing. Due to this, Wang and Shu (2010) recommended reconsideration of the

721 classification of thermal hazards of organic peroxide from the viewpoint of a proactive

722 approach to an intrinsically safer design by incorporating safer process operating conditions,

723 type and material of storage tanks for transportation, and firefighting via temperature control

724 and pressure relief systems.

725 Thermal runaway is another contributing factor for fire and explosion accident. Gustin 726 (2002) provided the case studies of thermal runaway reactions and stated that the study of

727 accident case histories can greatly reduce the rate of occurrence of runaway reaction

728 accidents. Similarly, Ho et al. (1998) analysed 65 incidents of runaway reactions and

emergency relief in Taiwan and classified them into several categories according to their causes, material involved, equipment types, reaction types and ignition sources. The study found that heat of reaction was the main cause in initiating thermal or pressure runaway.

Chemicals with National Fire Protection Association (NFPA) reactivity ratings of 2 and above can be categorized as reactive and can undergo runaway reactions, decompositions, or self-polymerizations with resulting temperature or pressure increase (Rao and Raghavan, 1996). Hence, these chemicals should be stored or handled appropriately avoiding hazardous environments.

For safe handling of HNS, containerized cargo handling is gaining popularity. This has led to the design of various containers suited to hazardous substances. For instance, an insulated storage system with balanced thermal energy flow (McCormick, 2011) and shipping and storage system for exothermic materials (Fine and Kurtz, 2000) can be a better solution 
to mitigate thermal runaway and decomposition hazards of chemicals. Moreover, the specialised containers may prevent leakage and defective packaging. However, the container's contents need to be properly secured and braced.

Simmons et al. (2009) compared the chemical incident reports of the U.S Department of Energy (May 2005) and U.S. Chemical Safety Board (U.S. Chemical Safety and Hazard Investigation Board, 2002) and argued that in both reports about $70 \%$ of chemicals involved in incidents were either not regulated or had NFPA instability rating of "0" or "1". Moreover, not all chemicals are rated and the NFPA rating system cannot be used for hazard identification of unrated chemicals. Likewise, Process Safety Management (PSM) regulation is not all-inclusive indicating that it does not regulate all chemicals. This indicates a need for more extensive hazard analysis approaches and more robust regulations.

Undeclared dangerous goods that entered the transport chain as a result of awareness, lack of regulations, mistakes/omissions during cargo transport booking, and deliberate nondeclaration have caused a number of fire and explosion accidents. More extensive incident and inspection data is required to estimate the rates of undeclared dangerous goods and develop quantitative frequencies for the model (Ellis, 2010). All stakeholders in the transport chain, such as manufacturers, shippers, cargo brokers, freight forwarders and freight consolidators should be more accountable for ensuring that dangerous goods are correctly and honestly declared (Foster, 2007). Furthermore, appropriate training should be given to crew 760 and personnel about regulations, precautions and packaging procedures in relation to 761 handling and transporting dangerous goods. Simmons et al. (2009) proposed that academia, 762 industry, and government join together and establish training and experience requirements to 763 remedy risk of chemical hazards. 


\subsection{Prevention of electrical faults}

In marine operations, electrical faults are caused by several factors, as discussed in section 2.4. Prevention of these causes is essential because a simple fault can be catastrophic in ships. For instance, a minor electrical spark may be an ignition source for an extreme fire and explosion event. Arcing fault is a common cause of electrical fires. Due to highimpedance, currents frequently fall within the range of normal working loads during arcing faults. Under this condition, circuit breakers frequently become ineffective against arcing faults (Land III and Fowler, 2009). The use of arc-resistant switchboards and the use of arc-

772 fault detection systems such as automatic arc-fault protection can significantly reduce the risk 773 to personnel when arcing occurs (Land III, 2008).

The ignition from poor connections (overheating or glowing connections) and 775 external heating resulting in short circuit or arcing can be prevented by ensuring proper 776 training to crew and fail-safe design of the system. Physical damage, voltage surges and 777 deterioration of electrical insulation present hazards which can cause electrical fires and 778 further research is required for physical mechanisms, minimum values, time frame for 779 ignition, industrial fires and metallurgical issues relating to electrical fires (Babrauskas, 2008).

780 Avoiding the use of defective or faulty electrical appliances may prevent short circuit 781 ignitions. Moreover, very minor incidents such as static electricity, electric spark and arc can 782 be sufficient to ignite accumulated combustible gas in confined or semi-confined areas and 783 avoiding their sources will reduce likelihood of fire and explosion events.

Skjong et al. (2016) stated that characterization of the marine vessel electrical grid 785 through real-time measurements, and the monitoring of fundamental parameters such as 786 impedance, harmonic currents and voltages, would be essential to ensure the safety, integrity, 787 and stability of the marine vessel power system. Since the intensive trend in use of electricity, 
the authors proposed that a smart grid similar to the modern land-based electrical system should be a necessity in marine vessels.

Using recent technologies, such as infrared thermography (IRT) in condition monitoring and inspection techniques, can enable identification of the presence of any thermal anomalies in electrical appliances (Jadin and Taib, 2012). The rapid development of computer programs, sensor, and signal processing technologies, and integration with artificial intelligence (AI) techniques, has made it possible to implement fault diagnosis and prognosis effectively (Liu et al., 2007). Previous researchers stated that the use of AI software agents will become essential for monitoring, diagnosing, and predicting system equipment faults, particularly important to critical systems and components such as engines, power generation, and thermal management.

For a fire to occur there must be the three basic components forming the fire triangle, 800 oxidizer, flammable material and a source of thermal energy. These factors combined 801 together result in the spread of fire and often lead to tragic consequences. In order to avoid or 802 control a fire, one of these factors should be avoided. Investigating the root causes of the 803 previous accidents reveals that the fuel leakage is the consequence of different fire and 804 explosion accidents occurring in the engine rooms (ATSB, 2008, 2016a; MAIB, 1999). In a 805 ship, fire occurs mostly in the engine room due to the high chance of having all three factors 806 simultaneously. Air (oxygen) and hot surfaces exist constantly in the engine room. When fuel 807 or lubricant oil sprays on hot surfaces, there is high chance of a fire and explosion event due 808 to the high flammability of conventional fuel or oil. Several questions such as 'are there 809 alternative fuels with less flammable property?' and 'does employing less flammable fuels or 810 oils reduce the likelihood of fire and explosion events?' can be raised. 


\section{Alternative fuels}

In this study, it is found that $31 \%$ fire and explosion accidents are caused by an accidental release of fuel or lubricating oil in the engine room. Replacing these highly

flammable materials with other less flammable fuels may help to reduce the risk of ignition during accidental leakage. In the quest for less hazardous fuels, effectiveness of alternative fuels needs to be reviewed from safety perspectives. According to DNV report (Chryssakis et al., 2014), alternative fuels that are already used or could potentially be used in shipping in the future include LNG, Liquefied Petroleum Gas (LPG), biofuels, synthetic fuels (FisherTropsch) (Takeshita and Yamaji, 2008), methanol and ethanol, Di-Methyl Ether (DME), biogas, hydrogen, biodiesel nuclear fuel and use of electricity for charging batteries and cold ironing. The EMSA report (2017) states that the currently considered alternative fuels in shipping such as LNG, electricity, biodiesel, and methanol and other fuels such as LPG, ethanol, DME, biogas, synthetic fuels, hydrogen (particularly for use in fuel cells), and nuclear fuel, could play a role in the future.

When analysing the viability and prospect of adoption of alternative fuels for use in shipping, safety considerations also need to be taken into account particularly the risks of fire and explosion accidents. In order to prevent or mitigate fire and explosion accidents in shipping, the effectiveness of alternative fuels needs to be assessed. The differences in chemistry and physical properties lead to different risks associated with transferring, dispensing, and handling alternative fuels. According to the EMSA (2017), one common challenge posed by the adoption of most alternative fuels is their physical and chemical characteristics, typically associated with low flashpoints, higher volatilities, different energy content per unit mass and in some cases toxicity.

In the current study, only fire and explosion related hazards that could be posed by alternative fuels are discussed. Inherently, all fuels present fire and explosion hazards if they 
are not stored or handled appropriately. Astbury (2008) explained the ignition and

combustion properties of alternative fuels in relation to fire and explosion hazards such as

850 handled safely.

851 Table 2. Ignition and combustion properties of some alternative fuels (Adopted from

852 (Astbury, 2008)).

\begin{tabular}{llllllll}
\hline Material & $\begin{array}{l}\text { Gross } \\
\text { Calorific } \\
\text { Value } \\
(\mathrm{MJ} / \mathrm{kg})\end{array}$ & $\begin{array}{l}\text { Octane } \\
\text { number }\end{array}$ & $\begin{array}{l}\text { Flash } \\
\text { point } \\
\left({ }^{\circ} \mathrm{C}\right)\end{array}$ & $\begin{array}{l}\text { Flammable } \\
\text { limits } \\
(\%, \mathrm{v} / \mathrm{v})\end{array}$ & $\begin{array}{l}\text { Auto } \\
\text { ignition } \\
\text { temperature } \\
\left({ }^{\circ} \mathrm{C}\right)\end{array}$ & $\begin{array}{l}\text { Resistivity } \\
(\Omega \mathrm{m})\end{array}$ & $\begin{array}{l}\text { Minimum } \\
\text { Ignition } \\
\text { Energy } \\
(\mathrm{mJ})\end{array}$ \\
\hline Ethanol & 29.73 & 100 & 13 & $3.3-19$ & 363 & $7.4 \times 10^{6}$ & $\mathrm{f}$ \\
Methanol & 22.72 & 99 & 11 & $6-36$ & 385 & $3 \times 10^{3}$ & 0.14 \\
LNG & 19.98 & $>100$ & -188 & $5-15$ & 537 & Gas & 0.28 \\
CrNG & 19.98 & 120 & Gas & $5-15$ & 537 & N/A & 0.28 \\
$\begin{array}{l}\text { LPG } \\
\text { (Propane) }\end{array}$ & 50.49 & 104 & Gas & $2.1-9.5$ & 450 & Gas & 0.25
\end{tabular}




\section{$\mathrm{f}=$ No data available}

The ignition and combustion properties of biodiesel are the same as those of conventional hydrocarbon oil-based diesel fuel, but it is a lower fire and explosion hazard than standard diesel because of a higher flash point. These properties make biodiesel and its blends with petroleum diesel safer to store, handle and use than conventional diesel fuel.

Methanol has a low rate of evaporation and low radiant heat energy which makes it a safer fuel because it is less likely to ignite in accidents and less harmful to people when it does (Nowell, 1994). Moreover, methanol is much less likely than gasoline to ignite in open air (well-ventilated areas) due to its low volatility. Methanol in a closed tank should be considered an explosion hazard because methanol fuel-air mixture in closed air tanks is 863 within its ignition limits (Maggio et al., 1991). However, in the case of spontaneous 864 combustion, methanol is classified between gasoline and diesel fuel (MacCarley, 2013). 865 Additionally, due to the lower volatility and higher flammable limit, pure methanol (M100) is 866 projected to result in as much as a 90 percent reduction in the number of automotive fuel 867 related fires compared to gasoline (Machiele, 1990). According to Fort (2011), METHAPU 868 project has successfully demonstrated that the on-deck methanol tank and fuel cell system did 869 not present any greater risk to the ship, occupants, or environment than that associated with 870 conventional fuels. Risk assessments are carried out in Stena Germanica, SPIRETH project 871 and Waterfront Shipping chemical tanker and were approved for installation, demonstrating 872 that safety considerations are not a barrier to the use of methanol fuel systems on ships (Ellis 873 and Tanneberger, 2015). Similar to methanol, ethanol fires are less hazardous than gasoline 874 and they can be readily extinguished with water (Bernton et al., 2010). It is safer than 
gasoline to store, transport and refuel (McWhorter, 2013). Thus, ethanol also presents a

moderate fire and explosion hazard if handled incorrectly.

The main hazard related to CrNG is gross leakage from the fuel feed pipe work. The 878 potential for ignition immediately after the accident (leakages) is greater for $\mathrm{CrNG}$ than 879 petrol as the flammable atmosphere will be far greater and likely to spread further and more 880 quickly (Astbury, 2008). However, natural gas is safer than gasoline and diesel in many 881 respects such as its ignition temperature is higher than gasoline and diesel and it is more 882 difficult to ignite accidentally in comparison to both (Kowalewicz, 1984). Additionally, it is 883 lighter than air and any leaks disperse rapidly upwards while gasoline and diesel pool on the 884 ground, increasing the danger of fire (Semin, 2008). Thus, natural gas presents fewer fire or 885 explosion hazards in well ventilated areas because of high auto-ignition temperature and 886 narrow explosive range.

887 LNG as a liquid is neither flammable nor explosive, but its vapour ignites when the 888 vapour-air mixture is 5-15\% (Kolwzan and Narewski, 2012). Fire and or explosion hazards 889 related to LNG are similar to CrNG though other hazards are different, for example, LNG has 890 roll-over and cryogenic hazards. Use of LNG as an alternative fuel is promising and has the 891 possibility of being a leading option in order to retain a substantial share of the world bunker 892 market because it is proven technology (about 40 ships are currently running on LNG), and is 893 meeting more than new emissions requirements and has less $\mathrm{CO}_{2}$ emissions (Semolinos et al., 894 2013). Moreover, LNG is already providing an economic alternative to diesel in the heavy 895 duty trucking industry, in port facility vehicles, and increasingly in marine and rail 896 applications (Kumar et al., 2011; Litzke and Wegrzyn, 2001). Thus, similar to any flammable 897 substance, appropriate design, regulations and personnel training are needed to maintain a 898 safe environment for application of LNG as a fuel. 
LPG is highly flammable and its leakage from a fractured pipe would form a large persistent flammable atmosphere, which would likely ignite (Astbury, 2008). As it is heavier than air, it tends to settle in trenches or maintenance pits increasing explosion hazards. Leak prevention measure is key to mitigating these hazards.

Hydrogen has a much lower minimum ignition energy $(0.017 \mathrm{~mJ})$ than any traditional hydrocarbon fuel and makes it far more sensitive to ignition than any other gaseous fuel (Astbury, 2008). Moreover, hydrogen has a much higher flame speed than any other gas and has wider flammable limits (4-75\%) with higher explosion hazards (Astbury, 2008).

Hydrogen ignition related accidents have occurred in the past resulting in severe consequences (Astbury and Hawksworth, 2007). Additional hazards may depend on its production and storage types.

This shows that there are certain properties which make some fuels more or less hazardous than others and the severity of risks posed by each alternative fuel may not be the same. In order to mitigate the fire and or explosion hazards of alternative fuels for commercial applications, necessary precaution measures should be put in place with appropriate fail-safe designs and their cost effectiveness needs to be assessed.

Existing studies on alternative fuels in shipping are mostly focussed on the possibility of emission reductions, however, secondary effects because of emission reduction measures are not extensively studied. Luo (2013) identified 8 possible side effects of emissions reduction measures, including both positive and negative impacts on emission reduction, world trade, economic efficiency, and the local environment. Maddox consulting (2012), identified 13 measures that have a negative marginal abatement cost (MAC) on emissions reduction in shipping, and analysed the six categories of barriers to their successful implementation, including technological, operational (or physical), regulatory, economic, market failure, and administrative barriers. Most cost effectiveness of alternative fuels is 
mainly assessed in relation to greenhouse gas reduction measures and not much emphasis is given to fire and explosion hazard reduction measures (Bouman et al., 2017; Hoffmann et al., 2012). Grahn et al. (2013), analysed cost effectiveness of LNG, fuel cells, hydrogen, synthetic fuels (gas-to-liquid (GTL)) and biofuel using the Global Energy Transition model (GET-RC 6.2). This was conducted based on global energy system modelling aiming to analyse fuel choices in the shipping sector under stringent Carbon dioxide $\left(\mathrm{CO}_{2}\right)$ constraints and reached the following conclusions;

1. A transition from oil-based fuels to an alternative fuel could be cost-effective in the next $10-20$ years,

2. LNG could be a major fuel in the shipping sector between 2020 and 2070 , depending on the cost of the storage tank,

3. After 2070, a variety of fuels; hydrogen, synthetic fuels and biofuels will be chosen depending on the characteristic of the ship,

4. Time of transition and fuel choices are affected by the chosen target of $\mathrm{CO}_{2}$ concentration, energy demand scenarios and the total supply of oil and natural gas. Findings of another study conducted by Taljegard et al. (2014) support these conclusions and state that (i) it is cost-effective to start the phase out of fuel oil within the shipping sector in the next decade; (ii) natural gas based fuels (liquefied natural gas and methanol) are the most probable substitutes during the study period; (iii) availability of carbon capture and storage (CCS), the $\mathrm{CO}_{2}$ target, the liquefied natural gas tank cost and potential oil resources affect marine fuel choices significantly; and (iv) biofuels rarely play a major role in the shipping sector, due to limited supply and competition for bioenergy from other energy sectors. However, neither study incorporated all variables nor uncertainties such as engine efficiency, regulatory impact and cost of technology replacement or modification because some of the technologies are not yet commercial. This shows that there is a need for 
analysing cost effectiveness from safety perspective of alternative fuels incorporating adequate parameters in sensitivity analysis.

Regardless of inherent hazards and many uncertainties such as availability, cost and technology, some alternative fuels are already being used in marine vessels as a prime mover. Examples of marine vessels running on alternative fuels are (1) MS Bergensfjord (LNG fuelled RO-PAX), (2) Viking Lady (LNG Fuelled, also demonstrator project for Fuels Cells in the context of the FellowSHIP project) and (3) MV Stena Germanica (First Methanol fuelled ship conversion) (EMSA, 2017).

The proposed alternative fuels have both advantages and disadvantages at this stage in relation to fire and or explosion hazards and would demand further research in many aspects. Due to this, it is highly unlikely that any single technology or fuel has the potential to be the "silver bullet" to be able to meet energy challenge and security, and mitigate the effects of climate change and other harmful environmental impacts, because all the options are subject to constraints of some kind (Ball and Wietschel, 2009).

From the initial stage of the development of alternative fuels and technologies, the consideration of fire and explosion hazard mitigation measures could play a significant role in reducing fire and explosion accidents in shipping. Comparing flammability properties of potential alternative fuels, some alternative fuels have favourable and safer properties than traditional fuels, which certainly minimise the risks of fire and explosion if adequate precautions are adopted.

\section{Conclusions}

Fire and explosion accidents are reported as a common accident type in maritime transportation. Fire and explosion accidents that occurred in maritime transportation between 1990 and 2015 are reviewed and analysed in order to identify causal and underlying causes of these accidents. The causal factors of fire and explosion accidents are identified and 
categorised as human error, thermal reaction, electrical fault, mechanical failures and unknown.

The general causes of fire and explosion accidents in shipping show that human error is the most common contributing factor accounting for $48 \%$ of accidents. In most cases, it is found that skill based error, inadequate supervision and inadequate organisational processes have resulted in mechanical failures, chemical reactions and electrical fault. Moreover, it is found that $43 \%$ of human error is arose from maintenance related activities. HEM, better safety culture, design integration and system management, and neuro-ergonomics design are seen as some key approaches in managing human failure.

In this study, it is found that mechanical failure contributed to $22 \%$ of fire and explosion accidents. Deficient maintenance activity and inappropriate overhauls have been the main contributors to leakage and mechanical failure. Mechanical failure can be prevented by controlling corrosion, fatigue failure, and wear and creep which are further mitigated by adequate design and safety systems. Investigations of shipping accidents have shown that in most cases fire originated in the engine room and was caused by leakage of oil or fuel coming into contact with hot exhausts. It is suggested that the failure of engineering components can be controlled or prevented by proper design, better materials selection, avoiding manufacturing defects and overloading, and adequate maintenance.

Hot metal surfaces, static electricity and electrical sparks and arcs are the major sources of ignition causing fire and explosion. In this study, about $7 \%$ of accidents are found to be caused by electrical fires. The main contributing factors for electrical fires are improper altercations, improper initial installation, and deterioration due to aging, improper use, inadequate capacity and faulty product. Some studies claimed that investigators considered a fire as electrical without definite evidence which led to the ruling out of other potential causes. Because of the complexity involved in investigation of fires, most fire accidents 
discussed in this paper are considered as electrical fires based on circumstantial evidences.

Uses of arc-resistant switchboards and arc-fault detection systems such as automatic arc-fault protection can significantly reduce the risks of fire and shock. Moreover, application of smart grid similar to the modern land-based electrical system would help to better manage the electrical system in ships. It has been proposed that using recent technologies such as infrared thermography and $\mathrm{AI}$ in condition monitoring and inspection techniques may enable identification of the presence of any anomalies in electrical appliances or systems.

Thermal reaction has contributed $14 \%$ to fire and explosion accidents, and breach of guidelines or policies was found to be the main root cause of accident. Defective packaging, inadequate hazard identification and incorrect stowage have contributed to accidents in shipping. Additionally, undeclared dangerous goods due to lack of awareness of regulations, mistakes or omissions during cargo transport booking, and deliberate non-declaration, are also significant contributors to shipping accidents. In order to mitigate fire and or explosion from reaction, a robust and extensive hazard identification procedure or tool is needed and all stakeholders, including manufacturers and those involved in a transport chain, should be accountable for safe handling of commodities. Adequate safety analysis and effective training and education are found to be common recommendation in most accidents caused by thermal reaction. Moreover, it is found that in $9 \%$ of accidents, investigators could not conclusively identify causes of accidents. This shows that accident investigation may need more rigorous approaches and experts.

All fuels are prone to fire and or explosion risks, however, some fuels are less prone to risk of fire and explosion because of differences in flammability and combustion properties. In order to compare the fire and explosion hazards posed by different fuels, properties of some proposed alternative fuels are compared and it is found that at this stage, adoption of alternative fuels do not pose higher fire and explosion risks than conventional fuels. LNG, 
CrNG and methanol have suitable properties for mitigating fire and explosion hazards and appropriate management of their hazards could be safer than traditional fuels. The proposed alternative fuels have weaknesses and strengths in relation to fire and or explosion hazards and demands further studies in many aspects. Due to the lack of adequate studies and technological immaturity, at this stage, it is highly unlikely that any single alternative fuel has the potential to be able to mitigate fire and explosion risks, to meet energy challenge and security, and to mitigate the effects of climate change.

\section{References}

2006. Contship Containerlines, Ltd V. PPG Industries, 05-0267-cv. United States Court of Appeals for the Second Circuit.

2008a. Casualty and incident reports and analysis, Sub-Committee on dangerous goods, solid cargoes and containers, 13th session, Agenda item 6. International Maritime Organization. 2008 b. Sub-committee on dangerous goods, solid cargoes and containers, 13th session, Agenda item 20, Report to the Maritime Safety Committee. International Maritime Organisation.

2008c. United States court of appeals for the second circuit, 05-6116-cv, In re M/V DG HARMONY.

Abbassi, R., Khan, F., Garaniya, V., Chai, S., Chin, C., Hossain, K.A., 2015. An integrated method for human error probability assessment during the maintenance of offshore facilities. Process Safety and Environmental Protection 94, 172-179.

Ahrens, M., 2016. Home Structure Fires. National Fire Protection Association, NFPA Research, Quincy, MA.

Akten, N., 2004. Analysis of shipping casualties in the Bosphorus. Journal of Navigation 57 (03), 345-356.

Akten, N., 2006. Shipping accidents: a serious threat for marineenvironment. Journal of Black Sea/Mediterranean Environment 12 (3).

Allianz Global Corporate and Specialty, 2016. Safety and Shipping Review 2016, SE FritzSchaeffer-Strasse 9, 81737 Munich, Germany.

Allianz Global Corporate and Specialty, 2017. Safety and Shipping Review 2017 An annual review of trends and developments in shipping losses and safety, Munich, Germany.

American Bureau of Shipping (ABS), 2003. Review and Analysis of Accident Databases: 1990 - 1999 Data, Houston.

American Bureau of Shipping (ABS), 2014. Guidance notes on the implementation of human factors engineering into the design of offshore installations, Houston, TX 77060 USA Apostol-Mates, R., Barbu, A., 2016. Human error-The main factor in marine accidents. Scientific Bulletin 'Mircea cel Batran' Naval Academy 19 (2), 451-454. Astbury, G., Hawksworth, S., 2007. Spontaneous ignition of hydrogen leaks: a review of postulated mechanisms. International Journal of Hydrogen Energy 32 (13), 2178-2185. Astbury, G.R., 2008. A review of the properties and hazards of some alternative fuels. Process Safety and Environmental Protection 86 (6), 397-414. ATSB, 1995. Engine room fire aboard the tanker Team Heina. 
ATSB, 2007a. Independent investigation into the boiler explosions on board the Panamanian registrered bulk carrier Shirane off Newcastle, New South Wales 2 April 2007.

ATSB, 2007b. Independent investigation into the leakage of dangerous goods on board the Liberian registered container ship Kota Pahlawan off the coast of Australia on 16 June 2006. ATSB, 2008. Independent investigation into the engine room fire on board the Bahamas registered general cargo ship Baltimar Boreas off Newcastle, New South Wales 9 February 2007.

ATSB, 2010. Engine room fire on board the container ship Maersk Duffield in Moreton Bay, Queensland. ATSB, 2012a. Cargo hold fire on board BBC Baltic at Port Hedland, Western Australia. ATSB, 2012b. Thermal oil heater explosion on board the products tanker Qian Chi at Brisbane, Queensland 16 January 2011.

ATSB, 2016a. Engine room fire on board the bulk carrier Marigold. ATSB, 2016b. Fire on board the livestock carrier Ocean Drover. Babrauskas, V., 2001. How do electrical wiring faults lead to structure ignitions, Proc. Fire and Materials 2001 Conf, pp. 39-51.

Babrauskas, V., 2003. Ignition handbook. Fire Science Publishers, Issaquah, WA.

Babrauskas, V., 2008. Research on electrical fires: the state of the art. Fire Safety Science 9, 3-18.

Baker, C., McCafferty, D., 2005. Accident database review of human element concerns: What do the results mean for classification?, Proc. Int Conf.'Human Factors in Ship Design and Operation, RINA Feb. Citeseer.

Ball, M., Wietschel, M., 2009. The future of hydrogen-opportunities and challenges. International Journal of Hydrogen Energy 34 (2), 615-627.

Baltic Marine Environment Protection Commission (HELCOM), 2002. HELCOM Manual on Co-operation in Response to Marine Pollution within the framework of the Convention on the Protection of the Marine Environment of the Baltic Sea Area, (Helsinki Convention) Volume 2.

Baltic Sea Maritime Incidence Response Group (MIRG), 2017. Baltic Sea MIRG Project 2014-2016 Ship fire incident analysis. The Finnish Border Guard, Ministry for Foreign Affairs of Finland.

Barton, J., Nolan, P., 1989. Incidents in the chemical industry due to thermal runaway chemical reactions. Hazards X: Process Safety in Fine and Speciality Chemical Plants (115), 3-18.

Bejger, A., Drzewieniecki, J., 2015. Analysis of tribological processes occuring in precision pairs based on example of fuel injection pumps of marine diesel engines. Zeszyty Naukowe Akademii Morskiej w Szczecinie.

Beland, B., 1984a. Electrical Damages - Cause or Consequence? Journal of Forensic Science 29 (3), 747-761.

Beland, B., 1984b. Electricity as a Cause of Fires. Society of Fire Protection Engineers Boston, MA.

Béland, B., 1992. Fires of Electrical Origin. Fire and Arson Investigator 43 (2), 35-41. Bernton, H., Kovarik, W., Sklar, S., Griffin, B., Woolsey, R., 2010. The forbidden fuel: A History of Power Alcohol, Lincoln/London.

Bhandari, J., Khan, F., Abbassi, R., Garaniya, V., Ojeda, R., 2017a. Pitting Degradation Modeling of Ocean Steel Structures Using Bayesian Network. Journal of Offshore Mechanics and Arctic Engineering 139 (5), 051402.

Bhandari, J., Lau, S., Abbassi, R., Garaniya, V., Ojeda, R., Lisson, D., Khan, F., 2017b. Accelerated pitting corrosion test of 304 stainless steel using ASTM G48; Experimental 
1114 investigation and concomitant challenges. Journal of Loss Prevention in the Process

11115 Industries 47, 10-21.

Bouman, E.A., Lindstad, E., Rialland, A.I., Strømman, A.H., 2017. State-of-the-art technologies, measures, and potential for reducing GHG emissions from shipping - A review. Transportation Research Part D: Transport and Environment 52 (Part A), 408-421. Martensitic Steel X46Cr13. Materials 10 (4), 388.

BSU, 2014. Investigation Report 255/12: Fire and explosion on board the MSC Flaminia on 14 July 2012 in the Atlantic and the ensuing events. BSU, 2015. Investigation Report 99/13: Fire on the con-ro carrier Atlantic Cartier on 1 May 2013 in the Port of Hamburg.

Butt, N., Johnson, D., Pike, K., Pryce-Roberts, N., Vigar, N., 2013. 15 Years of Shipping Accidents: A review for WWF. Southampton Solent University, Project Report, Southampton. Bužančić Primorac, B., Parunov, J., 2016. Review of statistical data on ship accidents. Maritime Technology and Engineering, 809-814.

Campbell, R., 2016. Fires in Industrial or Manufacturing Properties. National Fire Protection Association One-Stop Data Shop, NFPA Research Quincy, MA.

Campbell, R., 2017. Electrical Fires. National Fire Protection Association, NFPA Research, Data and Analytics Division.

Celik, M., Cebi, S., 2009. Analytical HFACS for investigating human errors in shipping accidents. Accident Analysis \& Prevention 41 (1), 66-75.

Celik, M., Lavasani, S.M., Wang, J., 2010. A risk-based modelling approach to enhance shipping accident investigation. Safety Science 48 (1), 18-27. Chang, J.I., Lin, C.-C., 2006. A study of storage tank accidents. Journal of Loss Prevention in the Process Industries 19 (1), 51-59.

Clancey, V., 1987. Calcium Hypochlorite fire and explosion hazard, Hazards from pressure: exothermic reactions, unstable substances, pressure relief and accidental discharge: a threeday symposium. Pergamon Pr, p. 11.

ClassNK, 2010. Guidelines for the Prevention of Human Error Aboard Ships: Through the Ergonomic Design of Marine Machinery Systems. ClassNK NIPPPON KAIJI KYOKAI, Chiba 267-0056.

Daeid, N.N., 2004. Fire investigation. CRC Press.

Darbra, R.-M., Casal, J., 2004. Historical analysis of accidents in seaports. Safety Science 42 (2), 85-98. Transactions on Reliability 40 (5), 531-536.

Det Norske Veritas, 2000. Engine room fires can be avoided, DNV, Veritasveien, Norway. Dhillon, B., Liu, Y., 2006. Human error in maintenance: a review. Journal of quality in maintenance engineering 12 (1), 21-36. DMAIB, 2012. Marine Accident Report Charlotte Maersk Fire 7 July 2010.

Eleftheria, E., Apostolos, P., Markos, V., 2016. Statistical analysis of ship accidents and review of safety level. Safety Science 85, 282-292. Ellis, J., 2010. Undeclared dangerous goods-Risk implications for maritime transport. WMU Journal of Maritime Affairs 9 (1), 5-27. Ellis, J., 2011. Analysis of accidents and incidents occurring during transport of packaged dangerous goods by sea. Safety Science 49 (8), 1231-1237. 
Ellis, J., Tanneberger, K., 2015. Study on the use of ethyl and methyl alcohol as alternative fuels in shipping. European Maritime Safety Agency.

EMSA, 2017. Alternative Fuels.

Energy Institute, 2008. Guidance for corrosion management in oil and gas production and processing May 2008.

Fine, B.M., Kurtz, B.E., 2000. Method for shipping exothermic materials. Google Patents. Fort, E., 2011. Methanol as a Marine Fuel-The METHAPU project. Lloyds Register. Marindagen.

Foster, C., 2007. Misdeclared or undeclared dangerous goods cargoes: Ignorance, incompetence or deceit. The Swedish Club Letter 1, 16-17.

Grahn, M., Taljegård, M., Bengtsson, S., Andersson, K., Johnson, H., 2013. Cost-effective choices of marine fuels under stringent carbon dioxide targets, Proceedings of 3rd International conference on technologies, operations, logistics and modelling in Low Carbon Shipping, University College London.

Gustin, J.-L., 2002. How the study of accident case histories can prevent runaway reaction accidents from recurring. Process Safety and Environmental Protection 80 (1), 16-24. Hakkarainen, T., Hietaniemi, J., Hostikka, S., Karhula, T., Kling, T., Mangs, J., Mikkola, E., Oksanen, T., 2009. Survivability for ships in case of fire. Final report of SURSHIP-FIRE project [Laivojenselviytymiskyky tulipalossa. SURSHIP-FIRE-projektin loppuraportti]. Espoo. VTT Tiedotteita-Research Notes 2497, 120.

Harrald, J.R., Mazzuchi, T., Spahn, J., Van Dorp, R., Merrick, J., Shrestha, S., Grabowski, M., 1998. Using system simulation to model the impact of human error in a maritime system. Safety Science 30 (1), 235-247.

Hassel, M., Asbjørnslett, B.E., Hole, L.P., 2011. Underreporting of maritime accidents to vessel accident databases. Accident Analysis \& Prevention 43 (6), 2053-2063.

Hatayama, H., Chen, J., E. Vera, Stephens, R., Storm, D., 1980. A method for determining the compatibility of hazardous wasters. US Environmental Protection Agency (EPA), Washington, D.C.

Haveman, J.D., Shatz, H.J., 2006. Protecting the nation's seaports: Balancing security and cost. Public Policy Instit. of CA.

Hemmatian, B., Abdolhamidzadeh, B., Darbra, R.M., Casal, J., 2014. The significance of domino effect in chemical accidents. Journal of Loss Prevention in the Process Industries 29 (Supplement C), 30-38.

401196

Hetherington, C., Flin, R., Mearns, K., 2006. Safety in shipping: The human element. Journal of Safety Research 37 (4), 401-411.

HID Statistics Report (HSR), 2003. Offshore hydrocarbon releases statisitcs and analysis, 2002, HID Statistics Report HSE 2002 002. Human Safety Executive (HSE).

Hine, G.A., 2004. Fire scene investigation: an introduction for chemists. Analysis and Interpretation of Fire Scene Evidence (Ed.: JR Almirall, KG Furton), CRC Press, Boca Raton. Ho, T.C., Duh, Y.S., Chen, J., 1998. Case studies of incidents in runaway reactions and emergency relief. Process Safety Progress 17 (4), 259-262.

Hoffmann, P.N., Eide, M.S., Endresen, Ø., 2012. Effect of proposed CO2 emission reduction scenarios on capital expenditure. Maritime Policy \& Management 39 (4), 443-460.

Hollnagel, E., 2008. Risk+barriers=safety? Safety Science 46 (2), 221-229.

Islam, R., Abbassi, R., Garaniya, V., Khan, F.I., 2016. Determination of human error probabilities for the maintenance operations of marine engines. Journal of Ship Production and Design 32 (4), 226-234.

Islam, R., Yu, H., Abbassi, R., Garaniya, V., Khan, F., 2017. Development of a monograph for human error likelihood assessment in marine operations. Safety Science 91, 33-39. 

equipment by using infrared thermography. Infrared Physics \& Technology 55 (4), 236-245. Karahalios, H., 2015. The Management of Maritime Regulations. Routledge.

Karwowski, W., 2005. Ergonomics and human factors: the paradigms for science, engineering, design, technology and management of human-compatible systems. Ergonomics 48 (5), 436-463.

Karwowski, W., 2012. The discipline of human factors and ergonomics. Handbook of Human Factors and Ergonomics, Fourth Edition, 1-37.

Khan, F., Howard, R., 2007. Statistical approach to inspection planning and integrity assessment. Insight-Non-Destructive Testing and Condition Monitoring 49 (1), 26-36.

Kolwzan, K., Narewski, M., 2012. Alternative fuels for marine applications. Latvian Journal of Chemistry 51 (4), 398.

Kowalewicz, A., 1984. Combustion systems of high-speed piston IC engines.

Kumar, S., Kwon, H.-T., Choi, K.-H., Lim, W., Cho, J.H., Tak, K., Moon, I., 2011. LNG: An eco-friendly cryogenic fuel for sustainable development. Applied Energy 88 (12), 4264-4273. Kwiecińska, B., 2015. Cause-and-effect analysis of ship fires using relations diagrams. Zeszyty Naukowe Akademii Morskiej w Szczecinie. Land III, H.B., 2008. Determination of the cause of arcing faults in low-voltage switchboards. IEEE Transactions on Industry Applications 44 (2), 430-436.

Land III, H.B., Fowler, K.R., 2009. Sensor for detecting arcing faults. Google Patents.

Litzke, W.-L., Wegrzyn, J., 2001. Natural gas as a future fuel for heavy-duty vehicles. SAE Technical Paper.

Liu, L., Logan, K.P., Cartes, D.A., Srivastava, S.K., 2007. Fault Detection, Diagnostics, and Prognostics: Software Agent Solutions. IEEE Transactions on Vehicular Technology 56 (4), 1613-1622.

Luo, M., 2013. Emission reduction in international shipping - the hidden side effects. Maritime Policy \& Management 40 (7), 694-708. Machiele, P.A., 1990. Summary of the Fire Safety Impacts of Methanol as a Transportation Fuel. SAE International. Reductions in the Maritime Transport Sector. Maggio, M., Maze, T., Waggoner, K.M., Dobie, J., 1991. Challenges for Integration of Alternative Fuels in the Transit Industry. Transportation Research Record (1308). MAIB, 1999. Marine Accident Investigation Branch (MAIB) - Safety Digest 02/1999. MAIB, 2000. Report of the investigation of the fire on board Multitank Ascania in the Pentland Firth on 19 March 1999.

MAIB, 2007. Report on the investigation of the machinery breakdown and subsequent fire onboard Maersk Doha in Chesapeake Bay, off Norfolk, Virginia, USA 2 October 2006.

Major Hazard Incident Data Service (MHIDAS), 2002. Major Hazard Incident Data Service, OHS_ROM, Reference Manual.

Maleque, M.A., Salit, M.S., 2013a. Materials selection and design. Springer.

Maleque, M.A., Salit, M.S., 2013b. Mechanical failure of materials, Materials Selection and Design. Springer, pp. 17-38.

Manuel, M.E., 2011. Maritime risk and organizational learning. Ashgate Publishing, Ltd. Marine Incident Investigation Unit, 1997. Departmental investigation the accommodation fire on board the Taiwanese bulk carrier Ming Mercy off Port Kembla, NSW on 7 August 1997. Maritime Safety Committee 81st session, 2006. Study on incidents of explosions on chemical and product tankers, Report of the activities of the Inter-Industry Working Group (IIWG). Maritime Safety Committee: Internation Maritime Organization. 
McWhorter, J.D., 2013. Is Renewable Energy Sustainable: Case Study of the Product Life Cycle of Brazilian Ethanol, 3rd World Sustainability Forum 1-30 November 2013. Midland Engineering, L., 2017. Human Factors and Ergonomics.

Mouritz, A., Mathys, Z., 1999. Post-fire mechanical properties of marine polymer composites. Composite Structures 47 (1), 643-653.

Munich Re Group, 2002. Containers Transport. Technology. Insurance. Central Division: Corporate Communications, Koniginstrasse 107, 80802 Muchen Germany.

Nalli, K., 2010. Corrosion and its mitigation in the oil and gas industry. An overview. PM-

Pipeliner Report.

National Industrial Chemicals Notification and Assessment Scheme (NICNAS), 1995. Full Public Report: Sodium Ethyl Xanthate Priority Existing Chemical No. 5, AGPS, Canberra. National Research Council, 1991. Fishing vessel safety: blueprint for a national program. National Academies Press.

Niall, R., Roger, R., 2002. Liquefied gas fire hazard management: An overview of a forthcoming SIGTTO publication, Gastech 2002, Qatar.

Noroozi, A., Abbassi, R., Khan, F., MacKinnon, S., 2010. Comparative evaluation of human error probability assessment techniques, Third National Conference on Safety Engineering and HSE Management, pp. 1-10.

Nowell, G.P., 1994. On the road with methanol: The present and future benefits of methanol fuel. Acurex Environmental, Durham, NC, Technical Report (2474).

NTSB, 2013. Fire Aboard Vehicle Carrier M/V Alliance Norfolk. NTSB, 2015. National Transportation Safety Board Marine Accident Brief Fire Aboard Containership Gunde Maersk.

NTSB, 2016. Marine Accident Brief: Fire aboard Freighter Alpena.

O'Leary, M., Chappell, S.L., 1996. Confidential incident reporting systems create vital awareness of safety problems. ICAO journal 51 (8), 11-13, 27.

O’Neil, W.A., 2003. The human element in shipping. WMU Journal of Maritime Affairs 2 (2), 95-97.

Okoh, P., Haugen, S., 2013. Maintenance-related major accidents: classification of causes and case study. Journal of Loss Prevention in the Process Industries 26 (6), 1060-1070.

Okoh, P., Haugen, S., 2014. A study of maintenance-related major accident cases in the $21 \mathrm{st}$ century. Process Safety and Environmental Protection 92 (4), 346-356.

Ozcayir, Z., 2007. IMO-International Maritime Dangerous Goods (IMDG) Code and Amendment 33-06. JOURNAL OF INTERNATIONAL MARITIME LAW 13 (6), 451. Papanikolaou, A., Eliopoulou, E., Alissafaki, A., Mikelis, N., Aksu, S., Delautre, S., 2007. Casualty analysis of Aframax tankers. Proceedings of the Institution of Mechanical Engineers, Part M: Journal of Engineering for the Maritime Environment 221 (2), 47-60.

Parasuraman, R., 2003. Neuroergonomics: Research and practice. Theoretical issues in ergonomics science 4 (1-2), 5-20.

Paula, H., Cassa, G., Hansen, R., 1998. Investigation of Fuel Oil/Lube Oil Spray Fires On Board Vessels. Volume III.

Pennie, D., Brook-Carter, N., Gibson, W., 2007. Human factors guidance for maintenance, Human factors in Ship Design, Safety and Operation Conference.

Popoola, L.T., Grema, A.S., Latinwo, G.K., Gutti, B., Balogun, A.S., 2013. Corrosion problems during oil and gas production and its mitigation. International Journal of Industrial Chemistry 4 (1), 35. Journal of Loss Prevention in the Process Industries 9 (3), 199-204. 
1312 Reason, J., 2000. Human error: models and management. BMJ: British Medical Journal 320

11313 (7237), 768.

21314

${ }_{4}^{3} 1315$

Roberts, S.E., Marlow, P.B., 2002. Casualties in dry bulk shipping (1963-1996). Marine

Policy 26 (6), 437-450.

51316 Roberts, S.E., Marlow, P.B., Jaremin, B., 2012. Shipping casualties and loss of life in UK merchant shipping, UK second register and foreign flags used by UK shipping companies. Marine Policy 36 (3), 703-712.

Roberts, S.E., Pettit, S.J., Marlow, P.B., 2013. Casualties and loss of life in bulk carriers from 1980 to 2010. Marine Policy 42, 223-235.

Rothblum, A.M., 2000. Human error and marine safety, National Safety Council Congress and Expo, Orlando, FL.

Sam, B., 2012. World Maritime Day: shipping safety 100 years after the Titanic.

Schröder-Hinrichs, J.U., Baldauf, M., Ghirxi, K.T., 2011. Accident investigation reporting deficiencies related to organizational factors in machinery space fires and explosions.

Accident Analysis \& Prevention 43 (3), 1187-1196.

Schröder, M., Prause, G., 2016. Transportation of Dangerous Goods in Green Transport Corridors-Conclusions from Baltic Sea Region. Transport and Telecommunication Journal 17 (4), 322-334.

Schuda, R.S., 1991. The International Maritime Organization and the Draft Convention on Liability and Compensation in Connection with the Carriage of Hazardous and Noxious Substances by Sea: An Update on Recent Activity. U. Miami L. Rev. 46, 1009.

Scutti, J., McBrine, W., 2002. Introduction to failure analysis and prevention. Materials Park, OH: ASM International, 2002., 3-23.

Semin, R.A.B., 2008. A technical review of compressed natural gas as an alternative fuel for internal combustion engines. American J. of Engineering and Applied Sciences 1 (4), 302311.

Semolinos, P., Olsen, G., Giacosa, A., 2013. LNG as marine fuel: challenges to be overcome, 17th International Conference \& Exhibition on Liquefied Natural Gas, TOTAL Gas \& Power, Houston.

Shappell, S.A., Wiegmann, D.A., 1997. A human error approach to accident investigation: The taxonomy of unsafe operations. The International Journal of Aviation Psychology 7 (4), 269-291.

Shichuan, S., Liang, W., Yuhong, N., Xiang, G., 2012. Numerical computation and characteristic analysis on the center shift of fire whirls in a ship engine room fire. Safety Science 50 (1), 12-18. Asking the right questions. Journal of Chemical Health and Safety 16 (3), 34-39.

Simmons, F., Quigley, D., Whyte, H., Robertson, J., Freshwater, D., Boada-Clista, L., Laul, J., 2008. Chemical storage: Myths vs. reality. Journal of Chemical Health and Safety 15 (2), 23-30. review. Journal of Coatings Technology and Research 6 (2), 135-176.

Stephens, R.I., Fatemi, A., Stephens, R.R., Fuchs, H.O., 2000. Metal fatigue in engineering. John Wiley \& Sons. 
Takeshita, T., Yamaji, K., 2008. Important roles of Fischer-Tropsch synfuels in the global energy future. Energy Policy 36 (8), 2773-2784. choices of marine fuels in a carbon-constrained world: results from a global energy model. Environmental science \& technology 48 (21), 12986-12993.

Tamburello, S.M., 2011. On determining spontaneous ignition in porous materials. University of Maryland, College Park.

Tournadre, J., 2014. Anthropogenic pressure on the open ocean: The growth of ship traffic revealed by altimeter data analysis. Geophysical Research Letters 41 (22), 7924-7932. Troitzsch, J.H., 2016. Fires, statistics, ignition sources, and passive fire protection measures. Journal of fire sciences 34 (3), 171-198.

TSB, 1995. Marine Investigation Report: Crankcase Explosion Oil Tanker "IRVING NORDIC" off Île aux Oeufs, Quebec 11 March 1993.

TSB, 1999. Marine Investigation Report: Explosion and Fire Aboard the Petroleum Tanker Petrolab and the subsequent destruction of the Government Wharf at St. Barbe,

Newfoundland 19 July 1997.

U.S. Chemical Safety and Hazard Investigation Board, 2002. Hazard investigation: Improving Reactive Hazard Management. Uğurlu, Ö., 2016. Analysis of fire and explosion accidents occurring in tankers transporting hazardous cargoes. International Journal of Industrial Ergonomics 55 (Supplement C), 1-11. Uğurlu, Ö., Köse, E., Yıldırım, U., Yüksekyıldız, E., 2015. Marine accident analysis for collision and grounding in oil tanker using FTA method. Maritime Policy \& Management 42 (2), 163-185.

US Chemical Safety and Hazard Investigation Board, 2007. Case Study Hot work control and safety work practices at oil and gas production wells.

US Coast Guard, 1980. Cargo Compatibility Chart and Chemical Hazards Response Information System (CHRIS).

US Coast Guard, 2004. Report on the explosion and sinking of the chemical tanker Bow Mariner in the Atlantic Ocean on 28 February 2004. Marine Safety Office, Hampton Roads, Virginia. 56pp.

Vilchez, J.A., Sevilla, S., Montiel, H., Casal, J., 1995. Historical analysis of accidents in chemical plants and in the transportation of hazardous materials. Journal of Loss Prevention in the Process Industries 8 (2), 87-96.

Wagenaar, W.A., Groeneweg, J., 1987. Accidents at sea: Multiple causes and impossible consequences. International Journal of Man-Machine Studies 27 (5), 587-598.

Wang, Y.-W., Shu, C.-M., 2010. Calorimetric thermal hazards of tert-butyl hydroperoxide solutions. Industrial \& Engineering Chemistry Research 49 (19), 8959-8968. Wang, Y., Duh, Y., Shu, C., 2009. Thermal runaway hazards of tert-butyl hydroperoxide by calorimetric studies. Journal of thermal analysis and calorimetry 95 (2), 553-557.

Weng, J., Yang, D., 2015. Investigation of shipping accident injury severity and mortality. Accident Analysis \& Prevention 76, 92-101.

Whittingham, R., 2004. The blame machine: Why human error causes accidents. Routledge. WORKSAFE BC, 2017. Human Factors.

Yip, T.L., Port traffic risks - A study of accidents in Hong Kong waters. Transportation research. Part E, Logistics and transportation review 44 (5), 921-931. 